\title{
Peranan World Food Programme (WFP) Melalui Program Food For Assets (FFA) Dalam Upaya Mengurangi Potensi Rawan Pangan Di Indonesia (Studi Kasus: Nusa Tenggara Barat
}

\author{
Elin Dewanti \\ Program Studi Ilmu Hubungan Internasional, Fakultas Ilmu Sosial dan Ilmu Politik, Universitas Komputer Indonesia, Jl. \\ Dipatiukur No. ,Bandung, 40212, Indonesia
}

E-mail : elin_dewanti@yahoo.com

\begin{abstract}
This study was to determine the role of the World Food Programme (WFP) through the Food For Assets (FFA) in an effort to reduce the potential for food insecurity in West Nusa Tenggara 2008-2010. Researchers analyzed the various efforts made by WFP through the FFA in its efforts to reduce the potential for food insecurity in the region is categorized as having food insecurity in West Nusa Tenggara.

Author of the research methods used in this study is qualitative method, aims to describe the facts relating to the problem under study. Most of the data collected through library research, online data retrieval, documentation, and interviews. The data was then analyzed with the theories and concepts in International Relations, among others, The Role of International Organizations, and Non-Traditional Security Issues.

The results showed that the WFP has done its role as an international organization that focuses on food issues. WFP is providing food assistance to areas experiencing food insecurity in Indonesia, one of which is the West Nusa Tenggara. Such assistance is implemented in the form of FFA programs and activities to support efforts to reduce the potential for food insecurity in West Nusa Tenggara.
\end{abstract}

Keywords: WFP, FFA, International Organizations, Food Insecurity, West Nusa Tenggara

\begin{abstract}
Abstrak
Penelitian ini untuk mengetahui peranan World Food Programme (WFP) melalui program Food For Assets (FFA) dalam upaya mengurangi potensi rawan pangan di Nusa Tenggara Barat tahun 2008-2010. Peneliti menganalisis berbagai upaya yang dilakukan oleh WFP melalui program Food For Assets (FFA) dalam upayanya mengurangi potensi rawan pangan di wilayah yang dikategorikan mengalami rawan pangan di Nusa Tenggara Barat.

Metode penelitian yang digunakan penulis dalam penelitian ini adalah metode kualitatif, bertujuan untuk menggambarkan fakta-fakta yang berhubungan dengan masalah yang diteliti. Sebagian besar data yang dikumpulkan melalui studi kepustakaan, penelusuran data online, dokumentasi, dan wawancara. Data-data tersebut kemudian dianalisis dengan teori-teori dan konsep-konsep dalam Ilmu Hubungan Internasional, antara lain Peranan Organisasi Internasional, dan Isu Keamanan Non-Tradisional.

Hasil penelitian menunjukkan bahwa WFP telah melakukan perannya sebagai sebuah organisasi internasional yang berfokus terhadap permasalahan pangan. WFP memberikan bantuan pangan kepada wilayah yang mengalami rawan pangan di Indonesia, salah satunya adalah Nusa Tenggara Barat. Bantuan tersebut dilaksanakan berupa program yaitu FFA dan beberapa kegiatan untuk mendukung upaya mengurangi potensi rawan pangan di Nusa Tenggara Barat.
\end{abstract}

Kata Kunci: WFP, FFA, Organisasi International, Rawan Pangan, Nusa Tenggara Barat 


\section{Pendahuluan}

\subsection{Latar Belakang Masalah}

Pangan merupakan kebutuhan mendasar bagi manusia. Dalam perspektif negara, pangan menjadi kebutuhan utama bagi rakyat, dan kebutuhan tersebut sifatnya tidak bisa ditunda-tunda. Orang boleh saja untuk sementara waktu tidak berpakaian yang layak, tidak punya tempat tinggal yang layak, tidak dapat mengenyam pendidikan dengan baik, atau tidak mendapat fasilitas kesehatan yang memadai. Tetapi tidak demikian dengan pemenuhan kebutuhan pangan, pangan mesti ada setiap saat. Negara boleh menunda pembelian pesawat terbang manakala keuangan negara tidak mencukupi, tetapi negara tidak bisa menunda impor pangan ketika ketersediaan pangan dalam negeri tidak mencukupi dan rakyat terancam kelaparan (Khaeron, 2012:6).

Pangan merupakan kebutuhan dasar utama bagi manusia yang harus dipenuhi setiap saat. Hak untuk memperoleh pangan merupakan salah satu hak asasi manusia, sebagaimana tersebut dalam pasal 27 UUD 1945 maupun dalam Deklarasi Roma (1996). Pertimbangan tersebut mendasari terbitnya UU No. 7 Tahun 1996 tentang Pangan. Ketahanan pangan dan keamanan pasokan pangan bagi Indonesia yang antara lain dapat dicapainya swasembada pangan pokok. Selain itu ketahanan pangan dapat dicirikan juga dengan berkurangnya ketergantungan terhadap impor (http://tempo.co.id/hg/peraturan/2004/04/13/prn,200404 13-03,id.html Diakses pada 25 Agustus 2014).

Pada Konferensi Pangan Dunia pada tahun 1974, para negara bertekad mengurangi kelaparan. Namun hingga tahun 1996, lebih dari 20 tahun, tekad itu ternyata belum juga terwujud. Maka dari itu pada tahun 1996, Direktur Jenderal Organisasi Pangan dan Pertanian Dunia (Food and Agriculture Organization - FAO) Jacques Diouf memprakarsai Konferensi Tingkat Tinggi Pangan Dunia (World Food Summit). KTT ini berlangsung di markas Food and Agriculture Organization (FAO) di Roma, Italia. Pada 13-17 November 1996 dan diresmikan oleh Paus Johanes Paulus II, dan dihadiri pula oleh antara lain Presiden Soeharto. Melalui World Food Summit diharapkan tekad Perserikatan Bangsa-bangsa (PBB) dan negara-negara anggota untuk dapat menanggulangi masalah kelaparan. Realisasi masalah ini harus melibatkan itikad baik para negara dan itu memerlukan usaha yang sungguh-sungguh baik dalam skala nasional maupun internasional. Jika tidak, jumlah sumber daya alam seperti air akan terus merosot. Masalah pelanggaran batas akibat urbanisasi serta penggundulan lahan subur juga akan menjadi masalah yang serius. Tanpa tindakan pasti setiap negara, tetap tidak akan menemui jalan keluar dalam memenuhi kebutuhan pangan. Semua anggota Perserikatan Bangsa-bangsa secara resmi menyepakati, bahwa setiap negara bisa mencapai ketahanan pangan apabila mampu memberikan jaminan bahwa semua penduduk setiap saat pasti memperoleh makanan yang cukup sesuai dengan norma gizi untuk kehidupan yang sehat, tumbuh, dan produktif. Ancaman atau peluang kejadian sebagian penduduk atau daerah mengalami kerawanan pangan adalah merupakan indikator akhir dari sistem ketahanan pangan (Hanafie, 2010:272).

Komitmen Indonesia terhadap World Food Summit, ialah dengan Pemerintah Indonesia berupaya menanggulangi kerawanan pangan di Indonesia, artinya setiap wilayah di Indonesia harus bisa mencapai ketahanan pangan atau bisa mengurangi potensi rawan pangan, dan Indonesia menerima konsep ketahanan pangan dari World Food Summit, yang dilegitimasi pada Undang-Undang Pangan Nomor 7 tahun 1996 tentang Pangan. UU ini ditindaklanjuti dengan Peraturan Pemerintah Nomor 68 Tahun 2002. Ketahanan Pangan didefinisikan sebagai kondisi terpenuhinya pangan bagi negara sampai dengan perseorangan, yang tercermin dari tersedianya pangan yang cukup, baik jumlah maupun mutunya, aman, beragam, bergizi, merata, dan terjangkau serta tidak bertentangan dengan agama, keyakinan, dan budaya masyarakat, untuk dapat hidup sehat, aktif, dan produktif secara berkelanjutan. Tiga aspek ketahanan pangan adalah adanya Ketersediaan Pangan, Akses Terhadap Pangan, dan Pemanfaatan Pangan. Ketika kondisi pangan bagi Negara sampai dengan perorangan tidak terpenuhi, maka kondisi yang akan terjadi adalah kondisi kerawanan pangan, artinya adalah istilah ketahanan pangan (food resilience) merupakan kondisi kebalikan dari kerawanan pangan (food insecurity) (http://rulebookjica.ekon.go.id/indonesia/4948_UU_18_2012_i.html Diakses 7 April 2014).

Keadaan kerawanan pangan di wilayah-wilayah di Indonesia tentu harus ditanggulangi, jika tidak, kelaparan dan kemiskinan akan terus menjadi ancaman. Upayaupaya yang dilakukan anggota-anggota Perserikatan Bangsa-bangsa termasuk Indonesia untuk menanggulangi kerawanan pangan di dunia adalah salah satunya dengan cara memberikan bantuan pangan melalui Program Pangan Dunia (World Food Programme - WFP). World Food Programme (WFP) adalah badan dalam sistem Perserikatan Bangsa-bangsa (PBB). World Food Programme didirikan pada tahun 1961, dan mulai beroperasi pada tahun 1963, bertujuan menangani bantuan pangan. Secara tidak langsung World Food Programme berada di bawah pengawasan Badan Pangan dan Pertanian (Food and Agriculture Organization-FAO) di Roma, Italia. FAO merupakan badan khusus dalam sistem Perserikatan Bangsa-bangsa (PBB). Hingga tahun 2013, World Food Programme memiliki perwakilan yang tersebar di 80 negara, termasuk di Indonesia. World Food Programme juga bekerja untuk memenuhi amanat World Food Summit dalam mengurangi kelaparan global dan kemiskinan (http://www.kemlu.go.id/rome/Pages/InformationSheet. aspx?IDP=19\&l=id Diakses 11 Maret 2014).

Ketika World Food Programme (WFP) pertama kali dibentuk, Indonesia merupakan salah satu negara penerima bantuan. Pada 1964, bantuan pangan senilai 1 
juta dolar Amerika diberikan ke korban letusan Gunung Agung di Bali. World Food Programme (WFP) terus beroperasi di Indonesia selama kurang lebih 50 tahun hingga saat ini (tahun 1964 hingga tahun 2014). World Food Programme berhenti beroperasi di Indonesia pada tahun 1996 ketika Indonesia menunjukkan kemajuan pesat ke arah kemandirian pangan. Namun pada tahun 1998, World Food Programme kembali hadir di Indonesia, dengan memberikan subsidi beras bagi masyarakat rawan dan intervensi gizi yang diakibatkan oleh bencana kekeringan akibat El Nino dan krisis keuangan di Asia dan peranan World Food Programme pada bencana alam seperti bencana tsunami di Aceh pada tahun 2004. Sejak 1998, World Food Programme telah membantu lebih dari 20 juta masyarakat rawan pangan di Indonesia, terutama di daerah-daerah pasca bencana alam dan pergolakan ekonomi (World Food Programme Brochure, 2013).

Banyak program yang dijalankan oleh World Food Programme di banyak negara, termasuk di Indonesia. Dalam menjalankan programnya, World Food Programme memetakan wilayah-wilayah yang mengalami rawan pangan untuk bisa melaksanakan program apa yang tepat dan yang paling dibutuhkan oleh daerah rawan pangan tersebut. Sebelum melaksanakan program, World Food Programme memetakan kerawanan pangan di daerah-daerah yang

diprioritaskan untuk mendapatkan bantuan. Mengkategorikan rawan pangan, terdapat dua jenis kondisi rawan pangan, yaitu yang bersifat kronis (chronical food insecurity) dan yang bersifat transient atau sementara (transitory food insecurity). Rawan Pangan Kronis adalah keadaan rawan pangan yang berkelanjutan yang terjadi sepanjang waktu yang dapat disebabkan karena keterbatasan Sumber Daya Alam (SDA) dan keterbatasan kemampuan Sumber Daya Manusia (SDM). Sedangkan, Rawan Pangan Transient atau Sementara adalah keadaan kerawanan pangan yang disebabkan oleh kondisi yang tidak terduga antara lain berbagai musibah, bencana alam, kerusuhan, musim yang menyimpang (perubahan iklim) dan keadaan lain yang bersifat mendadak. Indikator kerawanan pangan kronis tercakup dalam 3 aspek atau dimensi rawan pangan yaitu: masalah kesehatan, masalah ketersediaan pangan, masalah kemiskinan. Sedangkan indikator untuk kerawanan pangan transient atau sementara, menggambarkan aspek dari pengaruh lingkungan alam dan iklim, meliputi indikator seperti: persentase daerah tak berhutan, persentase puso, daerah rawan longsor dan banjir, fluktuasi atau penyimpangan curah hujan (http://bkp.deptan.go.id/ Diakses 7 April 2014).

Rawan pangan di Indonesia tahun 2008, dikategorikan dalam dua rawan pangan, yaitu: pertama, rawan pangan kronis, terdiri dari beberapa provinsi: Papua 14 kabupaten (prioritas 1, 2, 3), Nusa Tenggara Timur 11 kabupaten (prioritas1, 2, 3), Papua Barat 5 kabupaten (prioritas 1), Kalimantan Barat 7 kabupaten (prioritas 2), Nangroe Aceh Darussalam 4 kabupaten (prioritas 2). Aspek rawan pangan: masalah kesehatan, masalah ketersediaan pangan, dan masalah kemiskinan.
Penyebab tingkat kerawanan pangan: tingginya angka kemiskinan, tidak ada akses listrik, tingginya underweight pada balita, tidak ada akses jalan kendaraan roda empat, tidak ada sumber air bersih. Kedua, rawan pangan sementara, terdiri dari beberapa provinsi: Kalimantan Tengah 6 kabupaten (prioritas 3), Sulawesi Tengah 5 kabupaten (prioritas 3), Nusa Tenggara Barat 4 kabupaten (prioritas 3). Aspek rawan pangan: masalah daerah tak berhutan, daerah puso, daerah rawan longsor dan banjir, fluktuasi (penyimpangan curah hujan), tidak ada akses air bersih, tingginya rasio kebutuhan produksi pangan, gagal panen (Food Security and Vulnerability Atlas of Indonesia, 2009).

Prioritas dibagi menjadi 3 yaitu: 30 kabupaten Prioritas 1, 30 kabupaten Prioritas 2, dan 40 kabupaten Prioritas 3, dengan jumlah penduduk sekitar 25 juta. 246 kabupaten lainnya dikelompokkan menjadi Prioritas 4-6. Perhatian yang lebih besar harus diberikan kepada kabupaten yang termasuk pada Prioritas 1 hingga 3 . Setelah memetakan daerah yang dikategorikan rawan pangan, selanjutnya dipilihlah program-program World Food Programme yang sesuai dengan kondisi rawan pangan disetiap daerah. Seperti Food For Assets (FFA), Cash and Vouchers, Response to HIV AIDS and TB, Makanan Sekolah (School Meals), dan lain-lain. Jika dilihat dari data rawan pangan di Indonesia tahun 2008, jelas bahwa propinsi yang paling rawan adalah Papua dan Nusa Tenggara Timur karena masuk kedalam kategori 1, 2, dan 3, namun penyebab tingkat kerawanan disana yang paling banyak disebabkan oleh tingginya angka kemiskinan dan tingginya underweight pada balita, maka dari itu yang perlu ditanggulangi lebih awal adalah persoalan gizi dan bantuan pangan langsung. Peneliti sendiri tertarik dengan progam Padat Karya Pangan (Food for Assets-FFA), program ini sudah dilaksanakan di Nusa Tenggara Barat, dimana Nusa Tenggara Barat berada pada prioritas 3 rawan pangan sementara. Nusa Tenggara Barat dipilih menjadi daerah yang diterapkan program Food For Assets (FFA) karna dijadikan sebagai model penanganan rawan pangan, juga Nusa Tenggara Barat dinilai telah memenuhi prinsip FFA yaitu kemitraan, artinya: kesiapan pemerintah daerah, pemberdayaan kelembagaan (mitra kerjasama: LSM Nasional dan Internasional), Organisasi Berbasis Masyarakat (Community Based Organizations - CBOs), pemberdayaan masyarakat, dan sebelum program FFA berjalan kondisi sumber daya harus layak dalam artian tersedia secara lokal (Food Security and Vulnerability Atlas of Indonesia, 2009).

Pemberian bantuan yang tepat agar masyarakat tidak kelaparan, tentu sangat diperlukan dengan segera. Namun yang menjadi masalah disini adalah, selain dana pemerintah yang terbatas, juga perlu dipikirkan formula bentuk bantuan seperti apa yang cocok sehingga masyarakat selain terbebas dari kelaparan juga mampu berproduksi dan berkonsumsi secara seimbang. Bantuan langsung berupa uang, beras ataupun bahan pangan lainnya kepada masyarakat, memang sangat membantu 
penanganan rawan pangan, tetapi dianggap tidak mendidik, dan menimbulkan ketergantungan yang semakin kuat kepada pemerintah, maka dari itu perlu adanya terobosan baru dalam penanganannya. Seperti pameo lama, jangan berikan masyarakat ikan, tapi berikan kepada mereka kail agar mereka tetap produktif dimasa mendatang. Apabila dicermati, akar dari permasalahan rawan pangan adalah karena perubahan iklim sehingga gagal panen dan stok pangan menjadi terbatas. Disisi lain masyarakat tidak punya alternatif pekerjaan dan pendapatan diluar sektor pertanian tradisional yang selama ini digeluti, daya beli terbatas sehingga kemampuan menyediakan makanan bagi diri dan keluarganya terbatas dan munculah rawan pangan dan kelaparan (World Food Programme Brochure, 2013).

World Food Programme melihat perubahan iklim sebagai risiko berlapis atas upaya mencapai ketahanan pangan sekaligus ancaman terhadap upaya dalam menghilangkan kerawanan pangan dan kemiskinan. Keadaan ini mempengaruhi mata pencaharian masyarakat yang rawan pangan. Perubahan iklim menyebabkan seringnya bencana alam yang berhubungan dengan iklim dan berakibat pada meningkatnya jumlah masyarakat yang rawan pangan. Hal tersebut membawa dampak negatif di setiap dimensi kerawanan pangan. WFP menggunakan teknologi pencitraan satelit, sistem informasi geografi, pemetaan kerawanan di sejumlah populasi tertentu, peringatan dini dan kesiapan darurat untuk membantu pemerintah dan mitra agar siaga mengantisipasi bencana alam. Bersama pemerintah Indonesia, WFP telah mengembangkan Peta Ketahanan dan Kerentanan Pangan (Food Security and Vulnerability Atlas - FSVA) untuk tingkat nasional dan propinsi dimana peta tersebut berperan penting dalam mengidentifkasi daerah-daerah rawan pangan dan kemudian mengidentifikasi kelompok masyarakat paling rawan terkena dampak terburuk dari bencana alam dan perubahan iklim (World Food Programme Brochure, 2013).

World Food Programme telah beroperasi di banyak daerah dengan tingkat kerawanan tinggi terhadap risiko perubahan iklim dan bencana-bencana alam. Melalui progam Padat Karya Pangan (Food for Assets - FFA), WFP berkolaborasi dengan Pemerintah Indonesia membuka kesempatan bagi masyarakat untuk membangun fasilitas pertanian skala kecil serta aset infrastruktur pedesaan yang menguntungkan bagi masyarakat. Aset-aset tersebut dirancang untuk menguatkan ketahanan mereka atas perubahan iklim dan dapat segera membantu kelansungan mata pencaharaian dan ketahanan pangan. Memanfaatkan pelajaran dari pengalaman, WFP lebih jauh lagi menguatkan kapasitas pemerintah untuk membantu

masyarakat-masyarakat rawan pangan untuk meningkatkan ketahanan mereka atas perubah iklim melalui alternatif mata pencaharian, sistem pertanian yang berkesinambungan, manajemen sumber daya alam dan pelestarian hutan. WFP juga terus menggunakan pengawasan ketahanan pangan, analisis dan pemetaan agar memudahkan para pembuat keputusan dan para praktisi dalam memprioritaskan sumber daya yang ada melalui bukti lapangan dan intervensi - intervensi terarah (World Food Programme Brochure, 2013).

Salah satu program dari World Food Programme yang dapat dilakukan untuk mengatasi potensi rawan pangan sekaligus meningkatkan kemampuan berproduksi didalam masyarakat adalah Program Padat Karya Pangan (Food For Assets - FFA). Karena kasus rawan pangan yang terjadi sebagian besar di daerah pedesaan, maka model kegiatan yang cocok adalah Program Padat Karya Pangan. World Food Programme berkolaborasi dengan Pemerintah Indonesia membuka kesempatan bagi wilayah yang rawan pangan untuk membangun fasilitas pertanian serta aset infrastruktur pedesaan yang menguntungkan bagi komunitas masyarakat melalui progam Food for Assets. Kegiatan

tersebut menitikberatkan pada pemberdayaan masyarakat dan kegiatan fisik. Pemberdayaan masyarakat yang dimaksudkan adalah mengajak masyarakat untuk ikut berpartisipasi dan bergotong royong dalam kegiatan padat karya dan konservasi alam. Aset-aset dirancang untuk menguatkan ketahanan mereka atas perubahan iklim dan dapat segera membantu kelansungan mata pencaharaian dan untuk bisa mencapai ketahanan pangan. Difokuskan pada kegiatan bergotong royong agar bagaimana akses ekonomi bisa terjamin dalam rangka meningkatkan taraf ekonomi dan kesejahtraan masyarakat. Program yang dirancang untuk pendayagunaan tenaga kerja penganggur dan setengah penganggur dimusim sepi kerja atau hilangnya pekerjaan serta pendapatan akibat bencana alam yang sulit diproyeksikan. Kegiatan padat karya dapat dilaksanakan sesuai dengan kebutuhan masyarakat dengan prioritas dan kriteria disesuaikan

kondisi daerah (http://www.wfp.org/food-assets Diakses 10 Maret 2014).

Program ini lebih pada prioritas akses jalan wisata tani bagi daerah-daerah dan dusun-dusun terisolir. Salah satu contohnya juga seperti pembangunan Daerah Aliran Sungai (DAS), lumbung pangan desa. Penguatan kelembagaan di tingkat desa melalui sistem pengelolaan aset milik masyarakat umum seperti pengelolaan embung-embung rakyat. Selain pemberdayaan masyarakat, masalah kemitraan dan pemberdayaan kelembagaan di desa itu juga sangat penting. Bagaimana aset masyarakat bisa dikelola dengan baik

untuk pendapatan ekonomi masyarakat

(http://www.sumbawanews.com/berita/kecamatan-

pujut-dan-janapria-lokasi-pad

at-karya-wfp Diakses 10 Maret 2014).

Indonesia adalah Negara agraris dan Negara maritim, dimana mata pencaharian mayoritas penduduknya dengan bercocok tanam. Secara geografis Indonesia yang juga merupakan Negara kepulauan memiliki potensi alam yang besar tidak hanya dalam bidang kelautan tapi juga dalam pengolahan pertanian. Potensi pertanian Indonesia yang tinggi salah satunya disebabkan wilayah indonesia yang memiliki wilayah 
daratan sepertiga dari luas keseluruhan dilewati barisan pengunungan dunia. Hal ini menyebabkan wilayah daratan Indonesia sangat subur. Oleh karena itu, tidak heran jika sebagian besar penduduk Indonesia bermata pencaharian sebagai petani. Namun pertanian diketahui merupakan sektor yang paling rentan terhadap dampak perubahan iklim. Di Indonesia, dampak perubahan iklim memiliki dampak besar terutama bagi wilayah yang dikategorikan rawan pangan (http://www.sharinginformasi.com/2013/12/negara-maritim-danagraris.html Diakses 10 Maret 2014).

Naiknya suhu permukaan bumi menyebabkan terjadinya kekacauan pola musim, khususnya di Indonesia. Dimana cuaca yang tidak menentu membuat para petani sulit dalam memperkirakan waktu untuk mengelola lahan dan memanen. Akibat perubahan iklim (climate change), Indonesia memiliki fenomena musim hujan cenderung lebih pendek. Di sisi lain, musim kemarau yang lebih panjang telah meningkatkan berbagai ancaman bencana bagi sektor pertanian. Ancaman bencana yang paling sering dialami para petani adalah hidrometeorologi (banjir, kekeringan dan angin puting beliung). Hal ini akan memiliki dampak serius terhadap lingkungan, produktivitas pertanian dan ketahanan pangan nasional (http://techno.okezone.com/ $\mathrm{read} / 2013 / 05 / 01 / 56 / 800423 /$ dampak-perubahan-iklimterhadap-pertanian-indonesia Diakses 11 Maret 2014).

Salah satu wilayah yang paling rawan terhadap ancaman perubahan iklim dan wilayah yang dikategorikan rawan pangan transient atau sementara adalah Nusa Tenggara Barat. Perubahan iklim menjadi ancaman serius bagi pertanian di Nusa Tenggara Barat. Petani masih sangat minim memahami proses adaptasi (penyesuaian) terhadap perubahan iklim yang berdampak sistematik bagi hasil pertanian. Kurangnya informasi utuh tentang perubahan iklim yang menghambat optimalisasi hasil produk pertanian. Sehingga, petani masih sering mengalami risiko gagal panen akibat kekeringan, banjir dan ledakan hama, maka dari itu Nusa Tenggara Barat bisa berpotensi mengalami kerawanan pangan kronis. Salah satu perubahan iklim seperti penurunan curah hujan di kawasan selatan, sebaliknya di kawasan utara mengalami peningkatan curah hujan. Artinya kawasan yang menurun curah hujannya, sangat berpotensi merusak sistem tanam pertanian, khususnya tanaman yang tidak memiliki potensi resistensi terhadap kekeringan. Kemudian krisis air untuk menopang kehidupan (air bersih) dan infrastruktur listrik. Di sisi lain, peningkatan curah hujan akan menjadi potensi bagi ancaman banjir yang merusak sarana dan prasarana pendukung pertanian. Fenomena perubahan iklim secara global telah meruntuhkan infrastruktur vital yang menopang kekuatan ekonomi nasional dan merusak lahan pertanian (http://techno.okezone.com/read/2013/0 5/01/56/800423/dampak-perubahan-iklim-terhadap-per tanian-indonesia Diakses 11 Maret 2014).

Sektor pertanian di Nusa Tenggara Barat sangat rawan terhadap perubahan iklim, padahal sebagian besar wilayah Nusa Tenggara Barat adalah tanah yang subur yang menjadi sumber utama mata pencaharian penduduk pulau Lombok yang 90\% adalah petani. Komoditas tanaman yang menjadi andalan utama para petani di Nusa Tenggara Barat adalah tembakau (mangrove), jagung, padi, kopi, dan kapas. Meskipun Nusa Tenggara Barat memiliki kekayaan alam yang melimpah dan juga menghasilkan padi yang melebihi kebutuhan daerahnya hingga 500.000 ton setara beras, ternyata menurut data FSVA di tahun 2008 beberapa kecamatan yang tergolong rawan pangan, yaitu 19 kecamatan di Lombok Timur, 11 kecamatan di Lombok Tengah, 10 kecamatan di Lombok Barat, 9 kecamatan di Dompu, 2 kecamatan di Lombok Utara. Hal itu dikarenakan tingkat kekurang berdayaan suatu sistem usaha tani dalam mempertahankan dan menyelamatkan tingkat produktivitas secara optimal dalam menghadapi cekaman perubahan iklim. Ada tiga faktor utama yang terkait dengan perubahan iklim yang berdampak pada sektor pertanian yaitu, perubahan pola hujan dan iklim ekstrim (banjir dan kekeringan), peningkatan suhu udara, dan peningkatan permukaan air laut (Food Security and Vulnerability Atlas of Nusa Tenggara Barat, 2010).

Nusa Tenggara Barat (NTB) adalah wilayah yang terus aktif menemukan alternatif solusi dalam

mengurangi potensi rawan pangan di daerahnya.Terjadinya kasus rawan pangan, menunjukkan bahwa masalah kerawanan pangan bukan masalah yang sederhana dan dapat diatasi sesaat saja, melainkan merupakan masalah yang cukup kompleks karena tidak hanya memperhatikan situasi ketersediaan pangan atau produksi disisi makro saja melainkan juga harus memperhatikan program-program yang terkait dengan fasilitasi peningkatan akses terhadap pangan dan asupan gizi baik ditingkat rumah tangga maupun bagi anggota rumah tangga itu sendiri. Mayoritas keluarga pedesaan di Nusa Tenggara Barat saat ini masih mengandalkan pertanian skala kecil dengan sistem irigasi menggunakan air hujan. Risiko perubahan iklim dan cuaca ekstrim memiliki efek negatif terhadap kehidupan masyarakat di Nusa Tenggara Barat, membuat mereka semakin berisiko mengalami kerawanan pangan yang kronis. Perubahan iklim di Nusa Tenggara Barat merupakan tantangan paling serius yang dihadapi, seiring dengan semakin tingginya dampak dari perubahan iklim seperti peningkatan frekuensi dan intensitas banjir dan kekeringan serta peningkatan periodisitas El Nino dan La Nina. Perubahan iklim yang dapat berdampak secara signifikan terhadap ketahanan pangan, baik dari aspek ketersediaan, distribusi dan konsumsi serta kualitas pangan dan gizi (http://www.tempo.co/read/news/2010/

01/31/058222435/Ada-100-Daerah-di-Kabupaten-se-In donesia-Rawan-Pangan Diakses 9 April 2014).

Pemerintah Provinsi Nusa Tenggara Barat terus berupaya mencari solusi agar Nusa Tenggara Barat mengurangi potensi rawan pangan kearah yang kronis, karena Nusa Tenggara Barat dikategorikan sebagai daerah rawan pangan sementara (transitory food insecurity). Kerawanan pangan sementara dapat juga 
dibagi menjadi dua sub-kategori, yaitu: pertama, menurut siklus, terdapat suatu pola yang berulang terhadap kondisi rawan pangan, akibatnya terjadi musim paceklik yang terjadi dalam periode sebelum panen, dan sementara, yang merupakan hasil dari suatu goncangan mendadak dari luar pada jangka pendek seperti kekeringan atau banjir. Kedua, konflik sipil, goncangan sementara walaupun dampak negatifnya terhadap ketahanan pangan, akibatnya dapat berlanjut untuk jangka waktu yang lama. Dengan kata lain, maka kerawanan pangan sementara dapat mempengaruhi orang-orang yang berada pada kondisi rawan pangan kronis dan juga orang-orang yang terjamin pangannya pada keadaan normal. Artinya jika kerawanan pangan sementara tidak diatasi maka akan berakibat kerawanan pangan yang kronis (Food Security and Vulnerability Atlas of Nusa Tenggara Barat, 2010).

Karena itu Pemerintah Indonesia sangat menyambut baik kolaborasi dan sinergi antara Pemerintah Provinsi Nusa Tenggara Barat dan World Food Programme (WFP) untuk mengurangi potensi rawan pangan di Nusa Tenggara Barat dalam mengantisipasi bencana alam dan perubahan iklim melalui salah satu programnya yaitu program Food For Asset (FFA) atau padat karya pangan atau juga sering disebut Food For Work. Upaya untuk mengurangi potensi rawan pangan di Nusa Tenggara Barat harus dapat menjamin ketersediaan, distribusi, dan konsumsi pangan yang cukup, aman, bermutu dan bergizi seimbang serta merata. Pemerataan dilaksanakan baik pada tingkat daerah, rumah tangga, maupun perorangan, serta harus dapat diwujudkan secara merata di seluruh wilayah sepanjang waktu dengan memanfaatkan sumber daya dan kelembagaan (www. krjogja.com/read/147096/page /tentang_kami Diakses 10 Maret 2014).

Maka berdasarkan penjelasan dan pemaparan dari latar belakang diatas, peneliti tertarik untuk melakukan penelitian dengan judul:

"Peranan World Food Programme (WFP) Melalui Program Food For Assets (FFA) Dalam Upaya Mengurangi Potensi Rawan Pangan Di Indonesia (Studi Kasus: Nusa Tenggara Barat Tahun 20082010)"

Ketertarikan peneliti terhadap penelitian ini didukung oleh beberapa mata kuliah Ilmu Hubungan Internasional yaitu antara lain:

1. Organisasi Internasional merupakan fokus kajian peneliti menyangkut keterlibatan Organisasi Internasional, di dalam matakuliah ini peneliti mempelajari mengenai peran aktor yang terlibat dalam interaksi antar Negara yang bersifat internasional dan menciptakan interaksi global.

2. Studi Ekonomi Negara Berkembang merupakan matakuliah yang mempelajari tentang berbagai macam permasalahan yang terjadi di Negara berkembang dan upaya apa saja yang dilakukan untuk Negara berkembang.

3. Ekonomi Politik Internasional merupakan matakuliah yang mempelajari bantuan luar Negeri, peran Organisasi Internasional dalam upaya memberi bantuan kepada Negara berkembang.

\subsection{Rumusan Masalah}

\subsubsection{Rumusan Masalah Mayor}

Berdasarkan latar belakang masalah diatas, untuk memudahkan penulis dalam melakukan pembahasan, penulis merumuskan masalah sebagai berikut:

"Bagaimana peranan World Food Programme (WFP) melalui program Food For Assets (FFA) dalam upaya mengurangi potensi rawan pangan di Nusa Tenggara Barat tahun 2008-2010?"

\subsubsection{Rumusan Masalah Minor}

1. Bagaimana kondisi kerawanan pangan di Nusa Tenggara Barat sebelum adanya program Food For Assets (FFA) World Food Programme (WFP)?

2. Upaya-upaya apa yang dilakukan oleh World Food Programme (WFP) melalui program Food For Assets (FFA) dalam upaya mengurangi potensi rawan pangan di Nusa Tenggara Barat?

3. Kendala apa yang dihadapi oleh World Food Programme (WFP) melalui program Food For Assets (FFA) dalam upaya mengurangi potensi rawan pangan di Nusa Tenggara Barat?

4. Apa hasil dari program Food For Assets (FFA) dalam upaya mengurangi potensi rawan pangan di Nusa Tenggara Barat?

\subsubsection{Pembatasan Masalah}

Penulis membatasi masalah penelitian dengan menitik beratkan pada upaya yang dilakukan World Food Programme (WFP) melalui program Food For Assets (FFA) dalam upaya mengurangi potensi rawan pangan di Indonesia. Masa waktu yang telah dipilih mulai tahun 2008 yaitu awal program Food For Assets (FFA) dilaksanakan selama 3 tahun hingga 2010 di Nusa Tenggara Barat, sesuai dengan Memorandum Saling Pengertian antara Pemerintah Republik Indonesia dan Program Pangan Dunia Perserikatan Bangsa-bangsa bagi Bantuan Untuk Pemulihan dan Rehabilitasi Gizi melalui Operasi Pertolongan dan Pemulihan (Protracted Relief and Recovery Operation-PRRO) No.10069.2 tahap kedua, yang merujuk pada Nota Kesepahaman:

1. Persetujuan Dasar antara Pemerintah Republik Indonesia dan Program Pangan Dunia Perserikatan Bangsa-bangsa, 28 Mei 1968.

2. Operasi Pertolongan dan Pemulihan No. 10069.0 "Bantuan Pangan Bagi Para Pengungsi Dan Masyarakat Miskin", 5 September 2002-2005.

3. Operasi Pertolongan dan Pemulihan NO.10069.1 "Bantuan Untuk Pemulihan dan Rehabilitasi Gizi” (Tahap Pertama), 25 April 2005-Maret 2008. 
PRRO tahap kedua akan memprioritaskan kawasan Indonesia Timur sebagai lokasi penyebaran bantuan pangan. Kawasan Indonesia Timur yang dimaksud meliputi Provinsi Nusa Tenggara Barat (NTB), Nusa Tenggara Timur (NTT), dan Papua. Studi kasus yang dipilih adalah Nusa Tenggara Barat, dimana program Food For Assets (FFA) World Food Programme (WFP) berjalan, dan Nusa Tenggara Barat dipilih karna dijadikan sebagai model penanganan rawan pangan, Nusa Tenggara Barat juga dinilai telah memenuhi prinsip FFA yaitu kemitraan, artinya: kesiapan pemerintah daerah, pemberdayaan kelembagaan (mitra kerjasama: LSM Nasional dan Internasional), Organisasi Berbasis Masyarakat (Community Based Organizations - CBOs), pemberdayaan masyarakat, dan pasca program FFA berjalan kondisi sumber daya harus layak dalam artian tersedia secara lokal.

\subsection{Maksud dan Tujuan Penelitian \\ 1.4.1 Maksud Penelitian}

Penelitian ini dimaksudkan untuk mengetahui bagaimana peranan World Food Programme (WFP) melalui program Food For Assets (FFA) dalam upaya mengurangi potensi rawan pangan di Nusa Tenggara Barat tahun 2008-2010.

\subsubsection{Tujuan Penelitian}

1. Untuk mengetahui kondisi kerawanan pangan di Nusa Tenggara Barat sebelum adanya program Food For Assets (FFA) World Food Programme (WFP).

2. Untuk mengetahui upaya-upaya apa yang dilakukan oleh World Food Programme (WFP) melalui program Food For Assets (FFA) dalam upaya mengurangi potensi rawan pangan di Nusa Tenggara Barat.

3. Untuk mengetahui kendala apa yang dihadapi oleh World Food Programme (WFP) melalui program Food For Assets (FFA) dalam upaya mengurangi potensi rawan pangan di Nusa Tenggara Barat.

4. Untuk mengetahui hasil dari program Food For Assets (FFA) dalam upaya mengurangi potensi rawan pangan di Nusa Tenggara Barat.

\subsection{Kegunaan Penelitian \\ 1.5.1 Kegunaan Teoritis}

Diharapkan dapat menambah wawasan peneliti mengenai peranan organisasi internasional didalam Hubungan Internasional, berbagai macam masalah yang terjadi di Negara berkembang. Menguji konsep-konsep yang di pergunakan dalam studi hubungan internasional, menjelaskan berbagai fenomena terkait upaya menganggulangi rawan pangan di suatu Negara, dan peran yang dijalankan oleh organisasi internasional.

\subsubsection{Kegunaan Praktis}

1. Diharapkan dapat menambah wawasan, ilmu pengetahuan, pengalaman dan kemampuan peneliti di bidang Ilmu Hubungan Internasional.

2. Sebagai bahan referensi bagi penstudi Hubungan Internasional dan umum.

\section{TINJAUAN PUSTAKA DAN KERANGKA PEMIKIRAN}

\subsection{Tinjauan Pustaka}

\subsubsection{Tinjauan terhadap World Food Programme}

Dalam jurnal eJournal Ilmu Hubungan Internasional 2013 yang berjudul "PERAN WORLD FOOD PROGRAMME (WFP) DALAM MENANGANI KRISIS PANGAN DI SOMALIA TAHUN 2007-2009”, Nita Anggeriani menggarisbawahi bahwa persoalan krisis pangan banyak terjadi di beberapa Negara dan umumnya di Negara berkembang. Pada tahun 1970 Somalia mengalami krisis pangan kesulitan akibat kemarau panjang. Pada tahun 2007 terdapat angka kelaparan mencapai $80 \%$ masyarakat dilanda kelaparan. Bantuan kemanusiaan pun diberikan oleh World Food Programme yang tujuan utamanya adalah untuk mengatasi masalah kelaparan dan meningkatkan pembangunan sosial ekonomi masyarakat. Kondisi Somalia sejak diturunkannya Siad Baree tahun 1991 Negara ini berubah menjadi Negara tanpa harapan hidup. Banyak rakyat Somalia yang hidup dalam kelaparan dan kemiskinan. Perserikatan Bangsa-bangsa (PBB) mengatakan bahwa anak menderita kekurangan gizi mencapai $30 \%$ serta hampir setengah dari populasi Somalia mengalami kesulitan hidup karena kelaparan akibat krisis pangan. Sehingga masuklah World Food Programme ke Somalia pada tahun 1971 dan mulai melakukan operasinya diwilayah tersebut. World Food Programme mulai menjalankan tugasnya dengan memberikan

bantuan-bantuan kemanusiaan agar dapat menangani masalah tersebut.

\subsubsection{Tinjauan terhadap Food For Assets}

Dalam kaitannya Food For Assets (FFA), sebuah berita dari website World Food Programme (WFP), yang di publish pada 11 September 2013, yang berjudul "Food-For-Assets or Food-For-Work Helps Farmers In Mali Diversify Their Production", menurut masyarakat di Mali, berkat program Food For Assets World Food Programme, program tersebut membantu masyarakat untuk membangun sebuah bendungan kecil di 
Ouelessebougou, di wilayah Koulikoro di Mali, FFA telah mampu melakukan diversifikasi produksi pertanian. Menurut para petani disana, sebelumnya mereka hanya mengolah millet. Para petani sangat bergantung pada hujan. Ketika tidak ada hujan, seperti yang terjadi pada tahun 2011, keluarga mereka kelaparan. Namun setelah ada program padat karya pangan tersebut, sekarang bisa lebih baik, karena mereka dapat mengontrol keadaan. Berkat air yang ditahan oleh bendungan, sekarang banyak aset yang tumbuh seperti padi, kentang, tomat dan tentu saja millet. Berkat program FFA juga mereka membangun tempat pemancingan ikan, sehingga mereka bisa makan yang lebih bergizi. Dan mereka menjual produknya, ke wilayah lain sehingga menghasilkan pendapatan bagi masyarakat sekitar. Ada sekitar 30 persen dari penduduk Koulikoro yang menderita kekurangan gizi kronis, ini adalah salah satu tingkat tertinggi di Mali, namun sebagian besar sereal di Mali diproduksi di Koulikoro. Kurangnya pembangunan membuat orang-orang dalam situasi kemiskinan yang tinggi, masyarakat menghabiskan sebagian besar sumber daya mereka pada satu atau dua makanan dasar yang tidak cukup untuk memberi mereka semua zat-zat gizi. Program FFA WFP di Mali bertujuan untuk membantu masyarakat di daerah-daerah rawan pangan kronis. Program ini dilaksanakan melalui pendekatan FFA yang memobilisasi masyarakat pedesaan untuk melakukan kerja intensitas yang tinggi. FFA menciptakan manfaat bagi seluruh masyarakat dan meningkatkan produktivitas pertanian. Dengan cara ini WFP membantu orang memenuhi kebutuhan pangan mendesak mereka sementara yang memungkinkan mereka untuk meningkatkan kemandirian mereka dalam jangka panjang. Empat puluh tujuh orang telah bekerja pada proyek ini. Dalam pertukaran pekerjaan mereka, mereka menerima dua kilogram jatah makanan kering millet dan beras per orang per hari. Distribusi pangan diatur secara mingguan dengan mitra pelaksana WFP. Bendungan memiliki manfaat yang tak terhitung bagi masyarakat, program ini merupakan insentif yang baik untuk laki-laki muda dari desa untuk tinggal di desanya bukannya berangkat ke kota-kota besar untuk mencari pekerjaan. Sekarang mereka ingin terus membantu keluarga mereka, mereka memiliki ambisi baru. Sekitar 2.000 orang tinggal di Ouelessebougou, di mana bendungan memberikan dorongan baru bagi perekonomian lokal . Di tepi bendungan, penduduk desa juga bereksperimen dengan tanaman baru. Kelor merupakan sayuran yang mengandung banyak vitamin, mineral dan protein, kelor dijual dengan harga tinggi di pasar lokal. Daun yang digunakan dalam pengobatan tradisional. Baobab juga terkenal di seluruh Mali kegunaannya untuk mengobati radang, dan digunakan dalam banyak resep tradisional. Masyarakat juga dapat memproduksi madu baobab dan memperoleh penghasilan yang baik dari itu.

\subsubsection{Tinjauan terhadap Pangan dan Kerawanan Pangan}

Dalam penelitian Pusat Analisis Sosial Ekonomi dan Kebijakan Pertanian yang berjudul Strategi Peningkatan Ketahanan Pangan Rumah Tangga Rawan Pangan, Ening Ariningsih dan Handewi P.S. Rachman menganalisis permasalahan kerawanan pangan rumah tangga dan alternatif strategi penanggulangannya. Hasil analisis diharapkan menjadi bahan masukan bagi pengambil kebijakan dalam upaya meningkatkan ketahanan pangan dan menanggulangi kerawanan pangan rumah tangga. Data yang digunakan adalah data Susenas (Survey Sosial Ekonomi Nasional) tahun 1996-2005 dari Badan Pusat Statistik. Hasil analisis menunjukkan bahwa proporsi rumah tangga rawan pangan di provinsi-provinsi luar Jawa khususnya wilayah Kawasan Timur Indonesia dan daerah pedesaan relatif tinggi dibanding wilayah Kawasan Barat Indonesia dan derah perkotaan, implikasinya adalah penanganan masalah rawan pangan perlu diprioritaskan pada wilayah-wilayah tersebut agar kesenjangan antara Kawasan Timur dan Barat Indonesia serta kesenjangan desa dan kota tidak semakin melebar. Terjadinya kasus rawan pangan dan gizi buruk di beberapa daerah menunjukkan bahwa masalah ketahanan pangan bukan masalah yang sederhana dan dapat diatasi sesaat saja, melainkan merupakan masalah yang

cukup kompleks karena tidak hanya memperhatikan situasi ketersediaan pangan atau produksi di sisi makro saja melainkan juga harus memperhatikan program-program yang terkait dengan fasilitasi peningkatan akses terhadap pangan dan asupan gizi, baik di tingkat rumah tangga maupun bagi anggota rumah tangga itu sendiri. Dalam era desentralisasi, diperlukan sinkronisasi dan koordinasi yang baik antara pemerintah pusat dan pemerintah daerah dalam pelaksanaan program-program penanggulangan rawan pangan dan gizi buruk tersebut.

\subsection{Kerangka Pemikiran}

\subsubsection{Hubungan Internasional}

Hubungan internasional yang pada dasarnya merupakan studi mengenai interaksi lintas batas Negara oleh state actor maupun non-state actor memiliki berbagai macam pengertian. Dalam buku "Pengantar Ilmu Hubungan Internasional" Anak Agung Banyu Perwita \& Yanyan Mochamad Yani. menyatakan bahwa:

"Studi tentang Hubungan Internasional banyak diartikan sebagai suatu studi tentang interaksi antar aktor yang melewati batas-batas Negara. 
Terjadinya Hubungan Internasional merupakan suatu keharusan sebagai akibat adanya saling ketergantungan dan bertambah kompleksnya kehidupan manusia dalam masyarakat internasional sehingga interdependensi tidak memungkinkan adanya suatu Negara yang menutup diri terhadap dunia luar" (Perwita \& Yani, 2005:3-4).

Hubungan internasional dapat dilihat dari berkurangnya peranan Negara sebagai aktor dalam politik dunia dan meningkatnya peranan aktor-aktor nonNegara. Batas-batas yang memisahkan bangsa-bangsa semakin kabur dan tidak relevan. Bagi beberapa aktor non-Negara bahkan batas-batas wilayah secara geografis tidak dihiraukan (Perwita \& Yani, 2005:3).

Berakhirnya Perang Dingin telah mengakhiri sistem bipolar dan berubah pada multipolar atau secara khusus telah mengalihkan persaingan yang bernuansa militer kearah persaingan atau konflik kepentingan ekonomi di antara Negara-negara di dunia. Pasca Perang Dingin, isuisu Hubungan Internasional yang sebelumnya lebih terfokus pada isu-isu high politics (isu politik dan keamanan) meluas ke isu-isu low politics (isu-isu HAM, ekonomi, lingkungan hidup, dan terorisme) (Perwita dan Yani, 2005:7).

Dalam usaha sebuah Negara untuk menyelesaikan suatu masalah yang bersifat regional maupun internasional bisa diselesaikan bersama dengan kerjasama, dalam kerjasama ini terdapat kepentingankepentingan nasional yang bertemu dan tidak bisa dipenuhi di Negaranya sendiri. Menurut Muhadi Sugiono ada beberapa faktor yang perlu diperhatikan dalam kerjasama internasional:

1. Negara bukan lagi sebagai aktor eksklusif dalam politik internasional melainkan hanya bagian dari jaringan interaksi politik, militer, ekonomi dan kultural bersama-sama dengan aktor-aktor ekonomi dan masyarakat sipil.

2. Kerjasama internasional tidak lagi semata-mata ditentukan oleh kepentingan masing-masing Negara yang terlibat di dalamnya, melainkan juga oleh institusi internasional, karena institusi internasional seringkali bukan hanya bisa mengelola berbagai kepentingan yang berbeda dari Negara-negara anggotanya, tetapi juga memiliki dan bisa memaksakan kepentingannya sendiri (Sugiono, 2006:6).

Dalam suatu kerjasama internasional bertemu berbagai macam kepentingan nasional dari berbagai Negara dan Bangsa yang tidak dapat dipenuhi di dalam negerinya sendiri. Kerjasama internasional adalah sisi lain dari konflik internasional yang juga merupakan salah satu aspek dalam hubungan internasional. Isu utama dari kerjasama internasional yaitu berdasarkan pada sejauh mana keuntungan bersama yang diperoleh melalui kerjasama tersebut dapat mendukung konsepsi dari kepentingan tindakan yang unilateral dan kompetitif. Kerjasama internasional terbentuk karena kehidupan internasional meliputi berbagai bidang seperti ideologi, politik, ekonomi, sosial budaya, lingkungan hidup, pertahanan dan keamanan (Perwita dan Yani, 2005:33-34).

Menurut penjelasan diatas, pada perkembangannya, kerjasama internasional kini tidak hanya dilakukan oleh Negara dengan Negara saja, tetapi aktor lain seperti organisasi internasional, individu dan organisasi nonpemerintah dapat melakukan kerjasama internasional, dan aktor-aktor tersebut mempunyai kepentingan dan tujuan sendiri dalam melaksanakan kerjasama internasional. Seperti Perserikatan Bangsa-bangsa (PBB) bekerjasama dengan Negara-negara anggotanya melalui World Food Programme (WFP) untuk membantu mengurangi potensi mengurangi potensi rawan pangan seperti di Indonesia.

\subsubsection{Organisasi Internasional}

Organisasi-organisasi internasional tumbuh karena adanya kebutuhan dan kepentingan mesyarakat antarbangsa untuk adanya wadah serta alat untuk melaksanakan kerjasama internasional. Sarana untuk mengkoordinasikan kerjasama antar-negara dan antarbangsa kearah pencapaian tujuan yang sama dan yang perlu diusahakan secara bersama-sama. Salah satu kajian utama dalam studi hubungan internasional adalah organisasi internasional yang juga merupakan salah satu aktor dalam hubungan internasional (Perwita \& Yani, 2005:91).

Ada beberapa macam penggolongan organisasi internasional. Suatu organisasi internasional dapat sekaligus menyandang lebih dari satu macam penggolongan, bergantung pada segi yang ditinjau

dalam menggolongkannya. Secara terperinci penggolongan organisasi internasional ada bermacammacam segi tinjauan berdasarkan delapan hal, yaitu sebagai berikut:

1. Kegiatan Administrasi: organisasi internasional antar pemerintah (Intergovernmental Organization / IGO) dan organisasi internasional Non-pemerintah (Non-Governmental Organization / NGO).

2. Ruang Lingkup (wilayah) Kegiatan dan Keanggotaan: organisasi internasional global dan organisasi internasional regional.

3. Bidang Kegiatan (operasional) Organisasi: bidang ekonomi, lingkungan hidup, pertambangan, komoditi (pertanian, industri) bidang bea cukai dan perdagangan internasional.

4. Tujuan dan Luas Bidang Kegiatan Organisasi: organisasi internasional umum dan organisasi internasional khusus.

5. Ruang Lingkup (wilayah) dan Bidang Kegiatan: global-umum dan global-khusus, regional-umum dan regional-khusus.

6. Menurut Taraf Kewenangan (kekuasaan): organisasisupranasional(supranational organization) dan organisasi kerjasama (cooperativeorganization) (Rudy, 2009:94-97). 
Teuku May Rudi mendefinisikan organisasi internasional dalam bukunya "Administrasi dan Organisasi Internasional" sebagai berikut:

"Pola kerjasama yang melintasi batas-batas negara, dengan didasari struktur organisasi yang jelas serta diharapkan atau diproyeksikan untuk berlangsung serta melaksanakan fungsinya secara berkesinambungan dan melembaga guna mengusahakan tercapainya tujuan-tujuan yang diperlukan serta disepakati bersama, baik antara pemerintah dengan pemerintah, maupun antara sesama kelompok non-pemerintah pada Negara yang berbeda"(Rudy, 2009:3).

Berdasarkan definisi diatas, maka Organisasi Internasional kurang lebih harus mengandung unsurunsur sebagai berikut:

1. Kerjasama yang ruang lingkupnya melingkupi batas-batas Negara.

2. Mencapai tujuan-tujuan yang disepakati bersama.

3. Mencakup hubungan antar pemerintah maupun non-pemerintah.

4. Struktur organisasi yang jelas dan lengkap.

5. Melaksanakan fungsi secara berkesinambungan (Rudy, 2009:3).

Berdasarkan hal-hal diatas, maka World Food Programme adalah Internasional Government Organization (IGO) yang mempunyai tujuan khsusus pada suatu bidang tertentu dan keanggotaannya terbuka untuk seluruh Negara, dalam artian tidak terbatas pada sekelompok Negara tertentu. World Food Programme (WFP) adalah badan dalam sistem Perserikatan Bangsabangsa (PBB) yang tidak membatasi jumlah anggotanya dan mempunyai tujuan khusus untuk yang menangani bantuan pangan bagi semua orang di dunia dan membantu suatu Negara untuk mencapai tujuannya yaitu mencapai ketahanan pangan yang di mandatkan oleh World Food Summit.

Negara-negara yang tergabung dalam keanggotaan suatu organisasi internasional berhak meminta bantuan berupa saran, rekomendasi atau aksi langsung berkaitan dengan masalah-masalah dimana pemerintah tidak dapat mengambil resiko dengan hanya bertindak melalui kebijakan nasionalnya. Bahkan saat ini organisasi internasional dapat mempengaruhi tingkah laku Negara secara tidak langsung, dimana kehadiran mereka (baca: organisasi internasional) mencerminkan kebutuhan suatu masyarakat dunia untuk bekerjasama dalam menangani suatu permasalahan. Peranan Organisasi Internasional terbagi dalam 3 (tiga) kategori, adalah sebagai berikut :

1. Sebagai instrumen, yaitu organisasi internasional digunakan oleh Negara-negara anggotanya untuk mencapai tujuan tertentu berdasarkan tujuan politik luar negerinya.

2. Sebagai arena, organisasi internasional merupakan tempat bertemu bagi anggotaanggotanya yang membahas dan membicarakan masalah masalah yang dihadapi. Tidak jarang organisasi internasional digunakan oleh beberapa Negara untuk mengangkat masalah dalam negerinya, ataupun mengangkat masalah dalam negeri orang lain dengan tujuan untuk mendapat perhatian internasional.

3. Sebagai aktor independen, organisasi internasional dapat membuat keputusankeputusan sendiri tanpa dipengaruhi oleh kekuasaan atau paksaan dari luar organisasi. Jelas bahwa suatu organisasi Internasional hanya bisa melakukan tugas dan fungsinya dengan mengambil keputusan dari tubuh organisasi internasional terkait. Dengan demikian semakin jelas bahwa organisasi internasional merupakan non-state actor (Aktor Non Negara) yang

mempunyai kedudukan dalam sistem Internasional (Archer dalam Perwita \& Yani, 2005:95).

Peranan organisasi internasional dapat digambarkan sebagai individu yang berada dalam lingkungan masyarakat internasional. Sebagai anggota masyarakat internasional, organisasi internasional harus tunduk pada peraturan-peraturan yang telah disepakati bersama. Selain itu, melalui tindakan anggotannya, setiap anggota tersebut melakukann kegiatan-kegiatan dalam rangka mencapai tujuannya (Perwita dan Yani, 2005:29).

Dari penjelasan diatas artinya peran World Food Programme (WFP) dapat dikatakan sebagai arena dimana diadakannya pertemuan tahunan Badan Eksekutif WFP dan membicarakan persoalan-persoalan yang dihadapi. Juga sebagai instrument, dimana World Food Programme (WFP) digunakan oleh Negara-negara anggotanya untuk mencapai tujuan tertentu dalam mencapai ketahanan pangan, upayanya dalam menjalankan fungsinya sebagai suatu organisasi internasional yang difokuskan pada bantuan pangan untuk Negara-negara yang membutuhkan bantuan pangan. Organisasi internasional sangat berperan sebagai aktor hubungan internasional karena organisasi internasional sebagai wadah atau instrument bagi koalisi antar anggota atau koordinasi kebijakan antar pemerintah, seperti bagaimana World Food Programme (WFP) berperan di Indonesia dalam mengurangi potensi rawan pangan di Indonesia, dimana Indonesia ikut menyepakati World Food Summit untuk mencapai ketahanan pangan. World Food Programme (WFP) melalui programnya Food For Assets (FFA) bekerja sesuai standar prosedur yang ditetapkan untuk memberikan rekomendasi untuk Pemerintah Indonesia, lalu kemudian bekerjasama dengan Pemerintah Indonesia dalam hal mencapai ketahanan pangan.

Suatu organisasi internasional yang bersifat fungsional sudah tentu memiliki fungsi dalam menjalankan aktivitasnya. Fungsi ini bertujuan untuk mencapai kepentingan yang hendak dicapai, berhubungan dengan pemberian bantuan dalam mengatasi masalah yang timbul terhadap pihak yang terkait. Fungsi organisasi internasional itu antara lain: 
1. Menyediakan hal-hal yang dibutuhkan bagi kerja sama yang dilakukan antar negara dimana kerja sama itu menghasilkan keuntungan yang besar bagi seluruh bangsa.

2. Menyediakan banyak saluran-saluran komunikasi antar pemerintahan sehingga ide-ide dapat bersatu ketika masalah muncul ke permukaan (Perwita \& Yani, 2005:97).

Dari definisi tersebut jelas, World Food Programme (WFP) membantu pemerintah membuat peta ketahanan dan kerentanan pangan atau Food Security and Vulnerability Atlas (FSVA). Peta Ketahanan dan Kerentanan Pangan dibuat untuk menyediakan sarana bagi para pengambil kebijakan untuk secara cepat dalam mengidentifikasi daerah yang lebih rawan, dimana investasi dari berbagai sektor seperti pelayanan jasa, pembangunan manusia dan infrastuktur, termasuk didalamnya program Food For Assets yang berkaitan dengan ketahanan pangan dapat memberikan dampak yang lebih baik terhadap penghidupan, ketahanan pangan dan gizi masyarakat di Indonesia.

\subsubsection{Isu Keamanan Non-Tradisional}

Sekelompok pakar yang dikenal dengan sebutan "The Copenhagen School", yaitu Barry Buzan, Ole Waever dan Jaap de Wilde terlebih dahulu menjelaskan tentang konsep keamanan tradisional dalam Studi Ilmu Hubungan Internasional, sehingga tampak perbedaan jelas antara konsep keamanan tradisional dengan konsep keamanan baru yang ditawarkan. Dalam konsep keamanan tradisional, keamanan dilihat sebagai isu keamanan dibidang militer dan negara sebagai aktor utamanya, sedangkan dalam pendekatan baru yang ditawarkan isu keamanan tidak lagi dilihat hanya dari kerangka konsep militer dan politik dengan hanya aktor negara saja melainkan isu keamanan harus dilihat dalam berbagai sektor, aktor dan level analisis. Barry Buzan dan kawan-kawan menjelaskan tentang isu keamanan tidak hanya ada dalam sektor militer tapi juga ada dalam sektor politik, sektor ekonomi, sektor kemasyarakatan dan sektor lingkungan. Aktor yang terlibat tidak lagi hanya negara melainkan juga Organisasi Internasional (Perwita \& Yani, 2005:120).

Hubungan internasional membahas banyak isu, dan adanya diskusi diantara pakar-pakar hubungan internasional tentang berbagai konsep sekuritisasi dijelaskan oleh Barry Buzan bersama Ole Waever dan Jaap De Wilde dalam buku mereka yang berjudul "Security a New Framework for Analysis". Dalam buku tersebut, terdapat pendekatan baru dalam memandang isu keamanan. Isu keamanan non-tradisional mulai mengemuka pada akhir dekade 1990-an, Barry Buzan, Ole Waever dan Jaap de Wilde mencoba memasukkan aspek-aspek diluar hirauan tradisional kajian keamanan, seperti misalnya masalah kemiskinan, kesehatan, lingkungan hidup, perdagangan manusia, terorisme, kerawanan pangan, bencana alam dan sebagainya sebagai bagian dari studi keamanan. Dengan memasukkan hal-hal tersebut kedalam lingkup kajian keamanan, maka The Copenhagen School mencoba memperluas obyek rujukan isu keamanan dengan tidak lagi berbicara melulu keamanan Negara, tetapi juga menyangkut keamanan manusia. Pandangan ini mengemuka sejak berakhirnya perang dingin yang ditandai dengan penurunan ancaman militer terhadap kedaulatan suatu Negara, tetapi pada saat yang sama adanya peningkatan ancaman terhadap eksistensi manusia pada aspek-aspek lain seperti kemiskinan, penyakit menular, bencana alam, kerusakan lingkungan hidup, terorisme dan sebagainya. Berangkat dari hal tersebut maka konsep keamanan pun tidak lagi berbicara mengenai keamanan negara namun juga mengenai keamanan manusia (Perwita \& Yani, 2005:122).

Kepedulian terhadap keamanan manusia (Human Security) semakin meningkat, terutama setelah laporan tahunan United Nations Development Programme (UNDP), Human Development Report 1994, cakupan human security ada tujuh bidang, yaitu: Keamanan Ekonomi, Keamanan Pangan, Keamanan Kesehatan, Keamanan Lingkungan, Keamanan Individu, Keamanan Komunitas, Keamanan Politik. Sejak saat itu perhatian terhadap isu keamanan manusia mulai melanda tidak saja para pakar tetapi pembuat keputusan. Namun demikian, terlepas dari makin besarnya keinginan untuk memasukkan konsep keamanan manusia sebagai agenda kebijakan, hingga saat ini belum ada kesepakatan mengenai bagaimana keamanan manusia itu harus dipahami dan bagaimana pula aplikasi konsep tersebut didalam politik praktis (Hermawan, 2007:13).

Pendapat Barry Buzan, keamanan berkaitan dengan masalah kelangsungan hidup (survival). Isu-isu yang mengancam kelangsungan hidup suatu unit kolektif tertentu akan dipandang sebagai ancaman yang eksistensial. Dalam bukunya: The South East Asian Community Complex, Buzan menyebutkan bahwa:

"Persoalan keamanan tidaklah mungkin hanya menjadi urusan satu Negara saja tetapi membutuhkan sebuah koordinasi regional maupun internasional" (Perwita \& Yani, 2005:122).

Perkembangan isu-isu strategis seperti globalisasi, demokratisasi, penegakan HAM dan fenomena terorisme telah memperluas cara pandang dalam melihat kompleksitas ancaman yang ada dan mempengaruhi perkembangan konsepsi keamanan. Ancaman tidak lagi hanya berupa ancaman militer tetapi juga meliputi ancaman politik, ancaman sosial, ancaman ekonomi, maupun ancaman ekologis. Permasalahan dan ancaman tersebut kemudian digolongkan menjadi bagian dari isu-isu keamanan non tradisional.

Berkaitan dengan judul penelitian, peneliti akan memfokuskan pada perspektif human security (keamanan manusia) dalam bidang keamanan pangan yang merupakan cabang dari pendekatan keamanan nontradisional. 


\subsubsection{Pangan dan Kerawanan Pangan}

Dalam Peraturan Pemerintah RI nomor 28 tahun 2004 tentang keamanan, mutu dan gizi pangan. Pangan diartikan sebagai segala sesuatu yang bersumber dari sumber hayati dan air, baik yang diolah maupun yang tidak diolah. Pengertian pangan adalah segala sesuatu yang berasal dari sumber hayati dan air, baik yang diolah maupun yang tidak diolah, yang diperuntukkan sebagai makanan atau minuman bagi konsumsi manusia, termasuk bahan tambahan pangan, bahan baku pangan, dan bahan lain yang digunakan dalam proses penyiapan, pengolahan, dan atau pembuatan makanan atau minuman (Peraturan Pemerintah Republik Indonesia. Nomor 28 Tahun 2004 Tentang Keamanan, Mutu dan Gizi Pangan: PP-No.-28-Th-2004.pdf).

Pangan merupakan kebutuhan hidup yang esensial. Sesuai dengan nalurinya manusia akan dapat melakukan apa saja untuk memperoleh pangan yang cukup bagi eksistensi hidupnya. Menurut Ir. Thomas Darmawan dalam "Pertanian Mandiri" beranggapan bahwa:

"Pangan merupakan salah satu kebutuhan hidup yang paling penting dan yang pertama kali harus dicukupi oleh setiap manusia. Namun hal tersebut sama sekali bukan berarti bahwa manusia diciptakan dan hidup hanya untuk makan, melainkan manusia secara bijaksana harus makan agar tetap bisa bertahan hidup dan melakukan

aktifitasnya secara optimal" (Darmawan, 2002:137).

Istilah pangan atau food dalam kata mandarin dituliskan dua bagian yang satu berarti manusia atau human dan yang lain berarti baik atau good. Hal itu berarti bahwa pangan sudah seharusnya bagus, bermutu dan aman bila dikonsumsi manusia. Istilah pangan lebih banyak digunakan sebagai istilah teknis, seperti misalnya teknologi pangan, bukan teknologi makanan, produksi pangan bukan produksi makanan, bahan tambahan pangan bukan bahan tambahan makanan. Istilah makanan digunakan bagi pangan yang telah diolah. Pangan merupakan kebutuhan dasar manusia yang terpenting disamping papan, sandang, pendidikan, kesehatan. Karena tanpa pangan tiada kehidupan dan tanpa kehidupan tidak ada kebudayaan. Kebutuhan pangan diutarakan secara naluri, bayi menangis pada saat lapar. Pangan adalah segala sesuatu yang berasal dari sumber hayati dan air, baik yang diolah maupun tidak, diperuntukan sebagai makanan atau minuman bagi konsumsi manusia termasuk bahan tambahan pangan, bahan baku pangan dan bahan lain yang digunakan dalam proses penyiapan, pengolahan atau pembuatan makanan dan minuman (http://bkp.riau.go.id/ Diakses 11 Maret 2014).

Menurut FAO, gambaran umum pangan di dunia, terdapat 3 (tiga) hal yang menjadi sebab mengapa masalah ketahanan pangan perlu diperbincangkan. Pangan adalah hak azasi manusia yang didasarkan atas 4 (empat) hal berikut:
1. Universal Declaration of Human Right (1948) dan The International Covenant on Economic, Social, and Cultural Rights (1966) yang menyebutkan bahwa "everyone should have an adequate standard of living, including adequate food, cloothing, and housing and that the fundamental right to freedom from hunger and malnutrition".

2. Rome Declaration on World Food Security and World Food Summit 1996 yang ditanda tangani oleh 112 kepala Negara atau penjabat tinggi dari 186 Negara peserta, dimana Indonesia menjadi salah satu di antara penandatangannya. Isinya adalah pemberian tekanan pada human right to adequate food (hak atas pemenuhan kebutuhan pangan secara cukup), dan perlunya aksi bersama antar Negara untuk mengurangi kelaparan.

3. Millenium Development Goals (MDGs) menegaskan bahwa tahun 2015 setiap Negara termasuk Indonesia menyepakati menurunkan kemiskinan dan kelaparan separuhnya.

4. Hari Pangan Sedunia tahun 2007 menekankan pentingnya pemenuhan Hak Atas Pangan.

Pada Undang-Undang Pangan Nomor 7 tahun 1996 tentang Pangan, Ketahanan Pangan didefinisikan sebagai kondisi terpenuhinya pangan bagi Negara sampai dengan perseorangan, yang tercermin dari tersedianya pangan yang cukup, baik jumlah maupun mutunya, aman, beragam, bergizi, merata, dan terjangkau serta tidak bertentangan dengan agama, keyakinan, dan budaya masyarakat, untuk dapat hidup sehat, aktif, dan produktif secara berkelanjutan. Ketahanan Pangan: Ketersediaan Pangan, Akses Terhadap Pangan, Pemanfaatan Pangan. Ketika kondisi pangan bagi Negara sampai dengan perorangan tidak terpenuhi, maka kondisi yang akan terjadi adalah kondisi kerawanan pangan, artinya adalah istilah ketahanan pangan (food security) merupakan kondisi kebalikan dari kerawanan pangan (food insecurity) (http://rulebookjica.ekon.go.id/Indonesia/4948_UU_18_2012_i.html Diakses 7 April 2014).

Terdapat dua jenis kondisi rawan pangan, yaitu yang bersifat kronis (chronical food insecurity) dan yang bersifat transien atau sementara (transitory food insecurity). Rawan Pangan Kronis adalah keadaan rawan pangan yang berkelanjutan yang terjadi sepanjang waktu yang dapat disebabkan karena keterbatasan (Sumber Daya Alam - SDA) dan keterbatasan kemampuan (Sumber Daya Manusia - SDM), sehingga menyebabkan kondisi masyarakat menjadi miskin. Sedangkan, Rawan Pangan Transien atau Sementara adalah keadaan kerawanan pangan yang disebabkan oleh kondisi yang tidak terduga antara lain berbagai musibah, bencana alam, kerusuhan, musim yang menyimpang (perubahan iklim) dan keadaan lain yang bersifat mendadak. Indikator kerawanan pangan kronis tercakup dalam 3 aspek atau dimensi rawan pangan yaitu: Masalah Kesehatan, Masalah Ketersediaan Pangan, Masalah Kemiskinan. Sedangkan indikator untuk kerawanan pangan transien atau 
sementara, menggambarkan aspek dari pengaruh lingkungan alam dan iklim, meliputi indikator seperti: Persentase daerah tak berhutan, Persentase Puso, Daerah rawan longsor dan banjir, Fluktuasi atau penyimpangan curah hujan (http://bkp.deptan.go.id/ Diakses 7 April 2014).

Jika sebagian masyarakat dalam satu wilayah terjadi kerawanan pangan, bisa dikatakan daerah tersebut belum berhasil membangun ketahanan pangannya. Karena itu, agar pembangunan ketahanan pangan di daerah bisa terlaksana dengan baik, komitmen yang tinggi saja belum cukup, tetapi harus:

1. Diikuti dan didukung dengan kelembagaan yang mantap dan bisa bersinergi dengan pemangku kepentingan di bidang pangan lainnya, serta tersedianya dana untuk mengoperasionalkan kegiatan yang sudah dirancang. Disini bisa dilihat dari peranan World Food Programme (WFP) melalui program padat karya (Food For AssetsFFA).

2. Panduan dari The Food Security and Vulnerability Atlas of Indonesia (FSVA),

pemerintah dapat lebih fokus dan memprioritaskan sumber daya yang ada untuk menangani masalah kerawanan pangan secara menyeluruh. Food Security and Vulnerability Atlas of Indonesia (FSVA) berperan sebagai panduan agar tercapai pemahaman yang lebih baik dari permasalahan dasar guna membangun kebijakan-kebijakan yang tepat dan strategis dalam mengurangi jumlah populasi rentan pangan. Informasi yang dihasilkan sangat penting sebagai dasar dalam perencanaan, penentuan kebijakan, koordinasi pelaksanaan program dan kegiatan penanggulangan kerawanan pangan.

3. Pemberdayaan masyarakat, kelembagaan nonformal yang tumbuh dan berkembang dengan baik sampai di pedesaan seperti kelompok wanita (pemberdayaan kesejahteraan keluarga, kelompok wanita tani dan lainnya) sangat penting dilibatkan dalam memperbaiki tingkat kesehatan dan gizi masyarakat atau keluarga.

Karena itu, kegiatan-kegiatan seperti pemanfaatan lahan pekarangan dengan pertanian terpadu, tanaman obat, sayur-sayuran dan buah-buahan perlu terus dikembangkan. Dengan begitu dapat meningkatkan pendapatan dan ekonomi rumah tangga.

4. Pembangunan lumbung pangan desa. Untuk menjaga agar ketersediaan pangan di suatu wilayah dapat selalu terjamin kecukupan pangannya, pemerintah daerah harus berperan aktif menginisiasi dan memfasilitasi pembangunan lumbung pangan desa, beserta kelembagaan dan manajemennya. Keberadaan lumbung-lumbung desa ini sangat penting dan strategis nilainya, terutama di saat membantu para petani dan keluarganya menghadapi masa- masa paceklik, di mana harga bahan pangan

cenderung selalu meningkat.

Melalui berbagai upaya di atas, diharapkan upaya mengurangi potensi rawan pangan di setiap wilayah akan semakin mantap. Dengan demikian berbagai masalah pangan, seperti kerawanan pangan dapat di atasi dengan baik (Badan Ketahanan Pangan. Sistem

Kewaspadaan Pangan dan Gizi (SKPG). PENGANTARSKPG.pdf).

\section{OBJEK DAN METODE PENELITIAN}

\subsection{Objek Penelitian}

Dalam penyusunan skripsi ini, penulis melakukan penelitian dengan mengambil objek penelitian pada World Food Programme (WFP) melalui program Food For Assets (FFA). Adapun penelitian ini dilakukan untuk mengetahui peranan World Food Programme (WFP) melalui program padat karyanya dalam upaya mengurangi potensi rawan pangan di Indonesia, studi kasus yang diteliti adalah di Nusa Tenggara Barat dimana program Food For Assets (FFA) berjalan.

\subsubsection{Gambaran Umum World Food Programme (WFP)}

\subsubsection{Sejarah Pendirian World Food Programme (WFP)}

Menurut D. John Shaw dalam bukunya The UN World Food Programme and the Development of Food Aid. Ide lahirnya World Food Programme (WFP) terjadi pada tahun 1960 yang pada awalnya digagas oleh George McGovern (Direktur pertama dari Food for Peace di Kantor Eksekutif Amerika Serikat) pada masa pemerintahan presiden John F. Kennedy (Shaw, 2001:6).

Perserikatan Bangsa-bangsa (PBB) mendirikan World Food Programme pada tahun 1961, lahir sebagai badan dalam sistem Perserikatan Bangsa-bangsa (PBB) yang menangani bantuan pangan, dan secara tidak langsung berada di bawah pengawasan Badan Pangan dan Pertanian (Food and Agriculture OrganizationFAO) di Roma, Italia (http://www.kemlu.go.id/ Diakses 14 Maret 2014).

World Food Programme (WFP) pertama kali beroperasi pada 1963 dengan tugas menggunakan bantuan pangan untuk mendukung pembangunan sosial dan ekonomi, menyediakan makanan dan logistik lainnya jika dalam keadaan darurat, dan secara umum mempromosikan world food security (ketahanan pangan dunia). World Food Programme adalah sebuah lembaga kemanusiaan terbesar di dunia yang berkantor pusat di Roma, Italia, juga memiliki kantor perwakilan yang tersebar di 80 negara. World Food Programme bekerja untuk membantu masyarakat yang tidak mampu memperoleh atau menghasilkan pangan baik bagi diri sendiri dan keluarganya. Setiap tahunnya, World Food Programme memberi makan sekitar 90 juta orang, dengan sebagian besarnya adalah anak-anak, di 80 
Negara yang mengalami krisis atau rawan pangan (http://www.wfp.org/Diakses 14 Maret 2014).

World Food Programme melakukan operasinya bersama dengan dua badan lain, yaitu (Food and Agriculture Organization-FAO) dan (International Fund for Agricultural Organization-IFAD) dengan melakukan kerjasama dan saling terkoordinasi. Tiga badan yang saling berhubungan ini disebut "Triple Alliance in Rome", karena ketiga badan ini berpusat di Roma, Italia. Bergerak secara komplementer. Ketiganya bekerja untuk memenuhi amanat World Food Summit dalam mengurangi kelaparan global dan kemiskinan. World Food Programme (WFP) melakukan operasi bantuan pangan, sedangkan Food and Agriculture Organization (FAO) bergerak melalui bantuan pembangunan pertanian secara teknis, dan International Fund for Agricultural Organization (IFAD) melakukan bantuan keuangan internasional (http://www.wfp.org/ab outwfp/partners/agencies.asp? section $=1 \&$ subsection $=4$ Diakses 14 Maret 2014).

\subsubsection{Tujuan dan Fungsi World Food Programme (WFP)}

World Food Programme (WFP) bergerak untuk menghapuskan kelaparan dan malnutrisi, dengan tujuan utama menghilangkan kebutuhan akan bantuan pangan. Strategi utama yang mendasari aktivitas World Food Programme adalah menyediakan bantuan pangan dengan tujuan:

a. Menyelamatkan manusia yang merupakan pengungsi dan dalam situasi darurat lainnya,

b. Memperbaiki gizi dan kualitas hidup masyarakat yang paling rentan pada saat mendesak,

c. Membantu membangun aset dan memperbaiki taraf hidup masyarakat miskin khususnya melalui program-programnya.

Dalam menjalankan tujuan utamanya World Food Programme mengimplementasikan program dan aktivitas bantuan pangannya dengan cara:

1. Membantu pembangunan ekonomi dan sosial dengan berkonsentrasi pada kebutuhan masyarakat dan Negara yang bersangkutan.

2. Membantu secara terus menerus dari saat darurat sampai terjadinya pembangunan dengan memprioritaskan pada pencegahan bencana dan rehabilitasi pasca terjadinya bencana.

3. Membantu menemukan korban konflik dan pihak yang membutuhkan sumbangan pangan, dan menyediakan kebutuhan mereka baik dalam hal pangan dan juga pembangunan.

4. Menyediakan layanan bagi Negara pendonor, badan-badan Perserikatan Bangsa-bangsa (PBB) dan (Non-Govermental Organization-NGOs) agar dapat konsisten pada tujuan World Food Programme dan melengkapi operasi World Food Programme.

World Food Programme (WFP) juga mengumpulkan kelebihan pangan yang terjadi di suatu negara dan menyalurkannya sebagai bantuan kemanusiaan untuk mengatasi keadaan darurat pangan di negara-negara yang dikategorikan sebagai Negara Low Income Food Deficit Countries (LIFDCs), bantuan tersebut diberikan oleh World Food Programme (WFP) dengan sasaran:

1. Untuk menutupi kekurangan pangan yang mendesak akibat bencana alam, konflik sosial dan akibat peperangan, dan

2. Untuk membantu pelaksanaan proyek-proyek pengembangan ekonomi sosial.

Berdasarkan rencana strategis World Food Programme 2008-2013, World Food Programme (WFP) dimandatkan untuk:

1. Menyelamatkan nyawa dan melindungi mata pencaharian dalam keadaan darurat,

2. Mencegah kelaparan akut dan berinvestasi dalam kesiapsiagaan dan tindakan mitigasi bencana,

3. Mengembalikan dan membangun kembali kehidupan dan mata pencaharian pasca-konflik, situasi pasca bencana atau situasi transisi,

4. Mengurangi kelaparan kronis dan kekurangan gizi,

5. Memperkuat kapasitas Negara-negara berkembang untuk mengurangi kelaparan, termasuk melalui bantuan dan pembelian lokal.

\subsubsection{Struktur Organisasi World Food Programme (WFP)}

World Food Programme (WFP) dipimpin oleh seorang Executive Director dan dibantu oleh seorang wakil (Deputy Executive Directors). Executive Director World Food Programme ditunjuk oleh Sekretaris Jenderal (Sekjen) PBB dan Direktur Jenderal FAO setelah berkonsultasi dengan Dewan (Board) World Food Programme (WFP) serta memiliki masa jabatan lima tahun. Executive Director bertanggung jawab terhadap Dewan dalam hal administrasi World Food Programme (WFP), dan implementasi program serta aktivitas yang telah dijalankan oleh World Food Programme (WFP), penyediaan kebutuhan dewan, pemilihan dan penunjukan untuk staf dan organisasi kesekretariatan, memberikan pengarahan kepada staf World Food Programme (WFP) dalam berkoordinasi dengan FAO staff Regulations and Rules dan beberapa peraturan yang dibuat oleh Executive Director dengan persetujuan Sekretaris Jenderal dan Direktur Jenderal dan penunjukan perwakilan World Food Programme (WFP) untuk Negara-negara anggota. Executive Director membawahi sebelas divisi, yaitu Inspector General and Oversight Services Division (OSD), Office of Evaluation (OEDE), Ethnics Office (OEDX), Policy,

Planning and Strategy Division (OEDP), Communications and Public Policy Strategy Division (OEDC), Office of Hunger Solutions (OEDH), Office of the Ombudsman (OEDO), Office of Executive Director (OED), Finance and Legal Division (FL), Operations and Management Department (OM), External Affairs and Resource Deve lopment Department (RE). Fungsi Executive Board: 
1. Untuk membantu mengembangkan dan mengkoordinir kebijakan bantuan pangan jangka panjang dan jangka pendek

2. Mengawasi dan mengarahkan managemen WFP

3. Untuk memeriksa, mengubah, dan menyetujui program dan proyek kegiatan yang diserahkan oleh Executive Director

4. Untuk memeriksa, mengubah, dan menyetujui anggaran program, proyek kegiatan dan memeriksa administrasi serta pelaksanaan program dan proyek kegiatan WFP yang telah disetujui

5. Melaporkan program dan kegiatan WFP setiap tahunnya, termasuk didalamnya keputusan ke sesi substantif dari Dewan Ekonomi dan Sosial dan Dewan FAO (http://www.wfp.org/about/exe cutive-directorDiakses 15 Maret 2014).

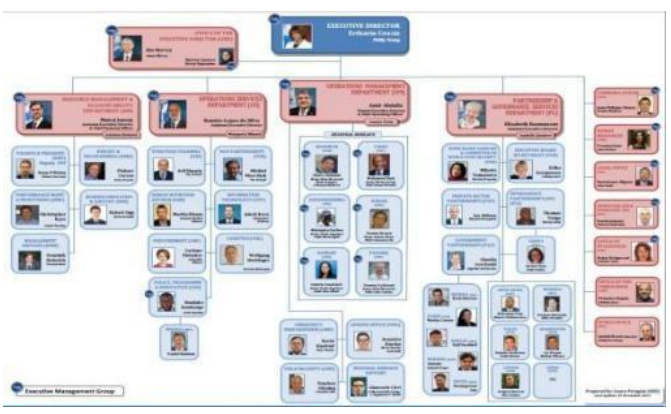

Sumber: (http://documents.wfp.org/stellent/groups/ public/documents/communications/wfp245047.pdf Diakses 14 Maret 2014).

Gambar 3.2

Struktur Organisasi World Food Programme (WFP)

\subsubsection{Program-program World Food Programme}

\subsection{Padat Karya Pangan (Food For Assets-FFA)}

Program Padat Karya Pangan (Food For Assets-FFA) (juga dikenal sebagai Food for Work) kegiatan ini menitikberatkan pada pemberdayaan masyarakat dan kegiatan fisik. Pemberdayaan masyarakat yang dimaksudkan adalah mengajak masyarakat untuk ikut berpartisipasi dan bergotong royong dalam kegiatan padat karya dan konservasi alam. Padat karya difokuskan pada kegiatan menumbuhkembangkan semangat bergotong royong agar bagaimana akses ekonomi bisa terjamin dalam rangka meningkatkan taraf ekonomi dan kesejahtraan masyarakat yang mandiri. Petani yang tidak mampu mengambil risiko bereksperimen dengan metode pertanian baru, dalam hal ini WFP memberikan bantuan dengan metode pertanian baru. Pengangguran yang tidak memiliki kesempatan untuk belajar keterampilan, WFP memberdayakan masyarakat untuk mereka ikut berpartisipasi dalam kegiatan program Food For Assets (FFA). World Food Programme (WFP) memberikan pekerjaan yang memungkinkan bagi masyarakat daerah rawan pangan untuk bisa bertahan. Ini adalah tujuan dari program Padat Karya Pangan (Food For Assets-
FFA) World Food Programme (WFP). Anggota masyarakat bekerja pada infrastruktur baru atau untuk belajar keterampilan baru yang akan meningkatkan ketahanan pangan rumah tangga atau masyarakat (http://www.wfp.org/food-assets Diakses 14 Maret 2014).

\subsection{Cash and Vouchers}

World Food Programme (WFP) memberikan ratusan ribu ton makanan setiap tahun, memberi orang lapar uang tunai atau voucher untuk membeli makanan. Uang tunai diberikan kepada orang-orang yang berjuang untuk menyediakan makanan bagi keluarga mereka, dan voucher dapat ditukar dengan makanan. Uang tunai dan voucher digunakan untuk mengatasi kelaparan di tempattempat di mana ada banyak makanan di pasar tapi di mana orang-orang miskin tidak mampu membelinya. Uang tunai dan voucher dapat mengurangi biaya transportasi dan menyimpan makanan, bermanfaat bagi perekonomian lokal, karena penerima menghabiskan uang di pasar lokal. Orang sering lebih memilih uang tunai dan voucher untuk bantuan makanan tradisional, karena mereka menawarkan lebih banyak pilihan dan variasi. WFP menggunakan cara-cara inovatif untuk memberikan bantuan, seperti "e-voucher" dikirim ke ponsel melalui pesan teks (http://www.wfp.org/cashand-vouchers Diakses 14 Maret 2014).

\subsection{Response to HIV AIDS and Tuberculosis}

Nutrisi yang tepat adalah cara yang penting untuk melindungi kehidupan dan mata pencaharian orang yang hidup dengan HIV dan Tuberkulosis (TB). Peningkatan ketahanan pangan juga memainkan peran penting dalam membantu untuk menghentikan penyebaran epidemi. Peran World Food Programme (WFP) dalam mendukung penanggulangan HIV dan TB, pada tahun 2011, sebanyak 2,3 juta orang di 38 Negara melalui program HIV dan TB. WFP mengakui tantangan yang unik memberikan bantuan di daerah-daerah yang menderita HIV tinggi dan prevalensi TB, kemiskinan dan rawan pangan yang mengakar dan sistem pemerintahan yang melemah. Mengingat tantangan yang ada dalam memerangi HIV dan TB, WFP berkomitmen untuk memaksimalkan keefektifan respon global. Dukungan makanan dan gizi WFP memainkan peran penting dalam mengurangi efek berbahaya dari HIV, TB, kerawanan pangan dan kekurangan gizi. Ini adalah cara yang penting dan

hemat biaya yang memungkinkan pengobatan, mengurangi angka kematian, dan mempromosikan pemulihan gizi (http://www.wfp.org/hiv-aids Diakses 14 Maret 2014).

\subsection{School Meals}

Visi World Food Programme adalah untuk mengurangi kelaparan di antara anak-anak sekolah sehingga kelaparan bukanlah hambatan bagi 
perkembangan mereka. Fakta bahwa hampir semua negara di dunia, baik maju dan berkembang, menyediakan makanan sekolah adalah bukti dari ini. Di banyak negara, langkah-langkah WFP untuk menyediakan makanan untuk sekitar 22 juta anak di 60 negara, sering kali ada daerah yang sulit dijangkau. WFP telah beroperasi dalam program sekolah selama lebih dari 50 tahun dan merupakan penyedia terbesar makanan sekolah. Maka dari pengalaman ini, WFP juga

mendukung pemerintah nasional dalam mengembangkan kualitas mereka sendiri, program pemberian makanan di sekolah yang berkelanjutan (http://www.wfp.org/schoolmeals Diakses 14 Maret 2014).

\subsubsection{Funding World Food Programme (Pendanaan WFP)}

Dalam menjalankan misinya, World Food Programme (WFP) tidak mendapatkan dana dari

Perserikatan Bangsa-bangsa (PBB), tetapi mendapatkannya dari kontribusi pemerintahan Negaranegara didunia, dan perusahaan-perusahaan. Untuk mendapatkan pihak-pihak yang ingin memberikan kontribusi bagi program World Food Programme (WFP) dan berhubungan dengan mereka dilakukan oleh External Affairs and Resource Deve lopment Department (RE). Sedangkan Finance and Legal Division (FL) bertugas untuk mengatur segala sesuatu yang berhubungan dengan keuangan. Pelaksanaannya tugas World Food Programme (WFP) dilapangan diatur oleh Operations and Management Department (OM) yang memiliki garis koordinasi dengan Executive Director (http://www.wfp.org/about/senior-leadership Diakses 14 Maret 2014).

World Food Programme merupakan satu-satunya organisasi dibawah naungan PBB yang tidak mendapatkan alokasi dana dari PBB. Kontribusi yang didapatkan WFP berasal dari proyek kemanusiaan dan pembangunan, yaitu:

1. Pemerintah merupakan sumber dana pokok bagi WFP. Sekitar lebih dari 60 pemerintahan yang menanggung pembangunan proyek kemanusiaan dari WFP. Pemerintah melakukan dukungan secara sukarela dan sepenuhnya terhadap pembangunan proyek-proyek kemanusiaan tersebut.

2. Perusahaan, melalui program yang dimiliki, setiap perusahaan dapat membuat sebuah kontribusi penting untuk memerangi kelaparan dan membantu mengurangi rawan pangan yang terjadi. Kontribusi yang diberikan oleh perusahaan dapat berupa sumbangan uang tunai perusahaan, produk atau layanan yang dapat membantu WFP dalam menangani rawan pangan. Beberapa perusahaan yang memberikan kontribusi untuk WFP adalah Citi, DSM, National Postcode Loterij (The Dutch Postcode Lottery), TNT, Unilever, Yum! Brands.

3. Individual, sumbangan individu dapat berupa :

a. Makanan khusus untuk anak-anak kelaparan di nurseries, b. Makanan insentif untuk mendorong keluarga miskin agar mengirim anak perempuan mereka ke sekolah,

c. Makanan sebagai alat untuk membayar orangorang yang membangun kembali sekolah, jalanan dan infrastruktur lain setelah terjadinya konflik dan bencana alam.

Sumbangan yang diberikan dapat berupa uang dalam dolar Amerika (cash), sumbangan dalam bentuk jasa (services), dan dalam bentuk komoditi pertanian (commodity). World Food Programme memiliki 20 pesawat terbang, kapal, dan lebih dari 5000 truk untuk mengirimkan makanan kepada yang membutuhkan. Selama tiga tahun pertama World Food Programme beroperasi (1963-1965) tidak kurang dari US\$ 100 juta sumber dana didapatkan oleh World Food Programme. Di tahun 2005, World Food Programme memperoleh dana hampir sekitar US\$2,8 juta dari kontribusi negaranegara. Seluruh dana sepenuhnya yang diperoleh berdasarkan sumbangan sukarela. Jenis sumbangan (pledge) kepada WFP dapat berbentuk :

a) Cash: Sumbangan yang diberikan dalam bentuk uang (US \$),

b) Services: Sumbangan dalam bentuk jasa,

c) Commodity: Dalam bentuk komoditi pertanian (http://www.wfp.org/about/

Funding Diakses 14 Maret 2014).

\subsubsection{Keanggotaan Indonesia di World Food Programme (WFP)}

Keanggotaan Indonesia di World Food Programme (WFP) sangat penting karena badan tersebut menangani program bantuan kepada pengungsi, anakanak sekolah (School Feeding Program) kepada pembangunan masyarakat desa, rehabilitasi lahan kritis, program bantuan masyarakat terasing, dan program bantuan pangan untuk musibah banjir. Selain itu, World Food Programme (WFP) juga dapat membantu dalam memformulasikan kebijakan bantuan pangan jangka panjang dan jangka pendek bagi Negara-negara anggotanya. Bantuan yang diterima Indonesia sejak tahun 1963 hingga 1991 dalam bentuk joint programme sebanyak 58 kegiatan dengan nilai total US\$ 210,819,881. Bentuk joint programme yang dilaksanakan di Indonesia diantaranya penanggulangan akibat bencana alam dan penanganan pengungsi, rehabilitasi irigasi, reboisasi daerah aliran sungai dan pengembangan lahan tanah tadah hujan. Karena kemajuan ekonomi di Indonesia sejak terciptanya swasembada beras tahun 1984, World Food Programme (WFP) telah menganggap Indonesia tidak termasuk lagi sebagai negara penerima bantuan World Food Programme (WFP). World Food Programme (WFP) bahkan telah menutup kantor perwakilannya di Jakarta sejak tahun 1995. Namun pada bulan Mei 1998, Indonesia kembali menjadi anggota World Food Programme (WFP) karena keadaan kesulitan pangan yang dialami oleh bangsa Indonesia sebagai dampak negatif dari krisis finansial Asia dan karena terjadinya 
kekeringan berkepanjangan akibat badai EL-Nino. Hal ini ditandai dengan diperolehnya bantuan World Food Programme (WFP) dalam bentuk Emergency Operation (EMOP 6008) yang kemudian disusul dengan program Protacted Relief and Recovery Operation (PRRO) yaitu program penyaluran beras bersubsidi bagi masyarakat di Jakarta dan Surabaya melalui Departemen Pertanian sebanyak 160.000 ton, yang dialoksikan untuk tahun anggaran. 1998/1999 sebanyak 112.000 ton untuk 539.701 kepala keluarga (KK) Pra Sejahtera dan pada tahun 1999/2000 sebanyak 48.000 ton untuk 231.299 KK Pra Sejahtera (http://www.deptan.go.id Diakses pada 15 Maret 2014).

Pada periode 2003-2005, Indonesia kembali menjadi anggota Executive Board WFP. Pemilihan Executive Board tersebut dilaksanakan pada sidang ke-123 Dewan FAO pada 28 Oktober-2 November 2002 di Roma, Italia. Indonesia sempat berhenti sebagai anggota Executive Board sejak tahun 1997 sampai 2001, karena pada saat itu Indonesia mendapat kehormatan menjadi ketua Dewan FAO. Kontribusi (pledge) Indonesia dari tahun 1963-1998 kepada World Food Programme (WFP) sebesar 2.289,95 juta ton komoditi pertanian senilai US\$ 2,760,480. Namun untuk tahun 1999 Indonesia tidak lagi memberikan bantuan karena saat itu Indonesia mengalami musibah kekeringan berkepanjangan akibat El-Nino, kebakaran hutan dan krisis ekonomi. Rakyat Indonesia memberikan bantuan pangan kepada rakyat Timor Leste, dilaksanakan di Timor-Leste pada tanggal 7 Mei 2004, bantuan Rakyat Indonesia kepada Rakyat Timor-Leste berupa: bantuan beras (Badan Urusan Logistik-BULOG): 35 ton, bantuan dari Yayasan Amal Masyarakat Pertanian Indonesia (YAMPI) sebesar Rp. 30 juta (lebih kurang seharga 15 ton beras), bantuan Badan Koordinasi Assosiasi Petani Tebu Rakyat Indonesia (BKAPTRI) 10 ton gula pasir, bantuan Indo

Food 500 kardus

(http://www.scribd.com/doc/128230157/Food-and-

Agriculture-Organizat

Ion Diakses 15 Maret 2014).

\subsubsection{Food For Assets (FFA) di Indonesia}

Meningkatkan ketahanan masyarakat dalam antisipasi bencana dan perubahan iklimmelalui program Padat Karya Pangan (Food for Asset - FFA), World Food Programme (WFP) memfasilitasi pembangunan aset masyarakat yang berguna untuk mengantisipasi dampak bencana alam dan perubahan iklim sekaligus memperkuat ketahanan pangan bagi masyarakat rawan di Provinsi Nusa Tenggara Barat (NTB) dan Nusa Tenggara Timur (NTT). Anggota masyarakat yang berpartisipasi dalam pembangunan aset menerima insentif beras sebagai pengganti waktu dan jasa yang mereka berikan (World Food Programme brochure, 2013).

Karena kasus rawan pangan yang terjadi sebagian besar di daerah pedesaan, maka model kegiatan yang cocok adalah Program Padat Karya Pangan (Food For
Assets-FFA). World Food Programme berkolaborasi dengan Pemerintah Indonesia membuka kesempatan bagi keluarga rentan rawan pangan untuk membangun fasilitas pertanian skala kecil serta aset infrastruktur pedesaan yang menguntungkan bagi komunitas mereka melalui progam Padat Karya Pangan (Food for AssetsFFA) atau bisa disebut juga Food For Work. Kegiatan tersebut menitikberatkan pada pemberdayaan masyarakat dan kegiatan fisik. Pemberdayaan masyarakat yang dimaksudkan adalah mengajak masyarakat untuk ikut berpartisipasi dan bergotong royong dalam kegiatan padat karya dan konservasi alam. Aset-aset dirancang untuk menguatkan ketahanan mereka atas perubahan iklim dan dapat segera membantu kelansungan mata pencaharaian dan ketahanan pangan. Difokuskan pada kegiatan menumbuhkembangkan semangat bergotong royong agar bagaimana akses ekonomi bisa terjamin dalam rangka meningkatkan taraf ekonomi dan kesejahtraan masyarakat. Merupakan program yang dirancang untuk pendayagunaan tenaga kerja penganggur dan setengah penganggur dimusim sepi kerja atau hilangnya pekerjaan serta pendapatan akibat bencana alam yang sulit diproyeksikan. Kegiatan padat karya dapat dilaksanakan sesuai dengan kebutuhan masyarakat dengan prioritas dan kriteria disesuaikan kondisi daerah. Polanya adalah mempekerjakan tenaga atau masyarakat selama 4 hari namun diberikan upah selama 6 hari, didukung seperti pengadaan material dan juga bibit tanaman. Program ini lebih pada prioritas akses jalan wisata tani bagi daerah-daerah dan dusundusun terisolir. Yang terpenting adalah penguatan kelembagaan di tingkat desa melalui sistem pengelolaan aset milik masyarakat umum seperti pengelolaan embung-embung rakyat.Jadi prinsipnya, selain pemberdayaan masyarakat, masalah kemitraan dan pemberdayaan kelembagaan di desa itu sendiri juga sangat penting. Bagaimana aset masyarakat seperti embung bisa dikelola dengan baik untuk pendapatan ekonomi masyarakat (http://www.sumbawanews.com /berita/kecamatan-pujut-dan-janapria-lokasi-padat-kary a-wfp Diakses 10 Maret 2014).

Kebijakan inti dan strategi yang mengatur kegiatan World Food Programme (WFP) adalah untuk memberikan bantuan pangan: untuk menyelamatkan kehidupan dalam pengungsi dan situasi darurat lainnya, untuk meningkatkan gizi dan kualitas hidup orang-orang yang paling rawan pada saat-saat penting dalam hidup mereka, dan untuk membantu membangun aset dan mempromosikan kemandirian masyarakat miskin, khususnya melalui program padat karya, antara lain:

1. Dalam kasus pertama, bantuan pangan sangat penting untuk perlindungan sosial dan kemanusiaan. Ini akan digunakan dengan cara yang sama, konsisten dengan menyelamatkan nyawa. Sedapat mungkin, pemberian bantuan makanan akan dikoordinasikan dengan bantuan pemulihan yang diberikan oleh organisasi kemanusiaan lainnya. 
2. Dalam kasus kedua, bantuan pangan merupakan investasisumber daya manusia.

3. Dalam kasus ketiga, menggunakan sumber daya masyarakat miskin yang paling melimpah, tenaga kerja mereka sendiri, untuk menciptakan lapangan kerja dan pendapatan juga membangun infrastruktur yang diperlukan untuk pembangunan berkelanjutan.

World Food Programme (WFP) memainkan peran utama dari bantuan darurat ke pembangunan. World Food Programme (WFP) akan memberikan prioritas untuk mendukung pencegahan bencana, kesiapsiagaan dan mitigasi dan pasca-bencana, kegiatan rehabilitasi sebagai bagian dari program pembangunan. Sebaliknya, bantuan darurat akan digunakan untuk melayani bantuan dan tujuan pembangunan. Dalam kedua kasus tujuan keseluruhan adalah untuk membangun kemandirian (http://www.wfp.org/about/strategic-plan Diakses 14 Maret 2014).

\subsubsection{Rawan Pangan di Indonesia}

Jumlah penduduk miskin terus meningkat di Indonesia, dengan demikian semakin banyak orang yang menghadapi rawan pangan. Terjadinya kasus rawan pangan di beberapa daerah, menunjukkan bahwa masalah rawan pangan bukan masalah yang sederhana dan dapat diatasi sesaat saja, melainkan merupakan masalah yang cukup kompleks karena tidak hanya memperhatikan situasi ketersediaan pangan atau produksi disisi makro saja melainkan juga harus memperhatikan program-program yang terkait dengan fasilitasi peningkatan akses terhadap pangan baik ditingkat rumah tangga maupun bagi anggota rumah tangga itu sendiri. Pangan sebagai kebutuhan pokok terpenting, memiliki keterkaitan langsung dan tidak langsung dengan kondisi kesehatan, kecerdasan dan produktivitas sumber daya manusia. Disamping itu pemenuhan kebutuhan pangan bagi seluruh penduduk Indonesia merupakan pondasi kuat untuk pembentukan kualitas manusia bangsa Indonesia, merupakan pilar bagi pembangunan ekonomi dan sektor lainnya, serta merupakan hak asasi setiap manusia atas pangan (http://www.tempo.co/read/news/2010/01/31/05822243 5/Ada-100-Daerah-di-Ka bupaten-se-Indonesia-Rawan-Pangan Diakses 15 Maret 2014).

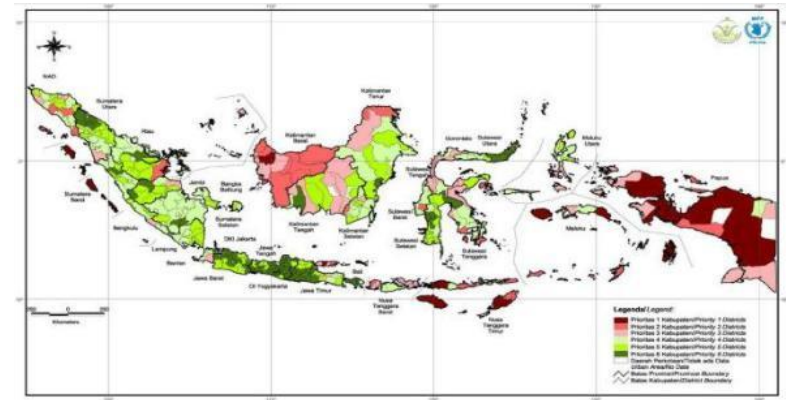

Sumber: (Food Security and Vulnerability Atlas of Indonesia, 2009).
Gambar 3.3

Peta Kerentanan Terhadap Kerawanan Pangan Indonesia

Dari gambar 3.3, World Food Programme dan Dewan Ketahanan Pangan Indonesia memetakan 346 kabupaten yang memiliki data lengkap untuk 9 indikator terkait kerawanan pangan. Di antara 346 kabupaten tersebut, maka ditetapkan 100 kabupaten dengan yang prioritas yang terdiri dari 30 kabupaten Prioritas 1, 30 kabupaten Prioritas 2, dan 40 kabupaten Prioritas 3, dengan jumlah penduduk sekitar 25 juta. 246 kabupaten lainnya dikelompokkan menjadi Prioritas 4-6. Perhatian yang lebih besar harus diberikan kepada kabupaten yang termasuk pada Prioritas 1 hingga 3.

1. 30 kabupaten prioritas 1, 11 kabupaten di provinsi Papua, 6 kabupaten di Nusa Tenggara Timur, 5 kabupaten di Papua Barat dan 8 kabupaten di 5 provinsi lainnya, dengan jumlah penduduk sekitar 5,3 juta. Tingkat kerawanan pangan terutama disebabkan karena tingginya angka kemiskinan, tidak ada akses listrik, tingginya underweight pada balita, tidak ada akses jalan kendaraan roda empat dan tidak ada sumber air bersih.

2. Dari 30 kabupaten di Prioritas 2, 7 kabupaten di provinsi Kalimantan Barat, 5 di kabupaten di Nusa Tenggara Timur, 4 kabupaten di Nangroe Aceh Darussalam, 3 kabupaten di papua dan 11 kabupaten di 9 provinsi lainnya, dengan jumlah penduduk sekitar 7,7 juta orang. Penentu utama kerawanan pangan di Prioritas 2 hampir sama dengan Prioritas 1 meskipun urutannya sedikit berubah yaitu: tingginya angka underweight pada balita, tidak ada akses kendaraam roda empat, tidak ada sumber air bersih, tingginya kemiskinan dan tidak ada akses listrik.

3. Dari 40 kabupaten Prioritas 3, 6 kabupaten di provinsi Kalimantan Tengah, 5 kabupaten di Sulawesi Tengah, 4 Kabupaten di NTB dan 25 kabupaten di 16 provinsi lainnya, dengan jumlah penduduk sekitar 12 juta. Kerawanan pangan pada Prioritas 3 terutama disebabkan karna tidak ada akses air bersih, tingginya rasio kebutuhan produksi, dan gagal panen.

\subsubsection{Potensi Rawan Pangan di Nusa Tenggara Barat (NTB)}

Nusa Tenggara Barat adalah sebuah provinsi di Indonesia. Sesuai dengan namanya, provinsi ini meliputi bagian barat kepulauan Nusa Tenggara. Dua pulau terbesar di provinsi ini adalah Lombok yang terletak dibarat dan Sumbawa yang terletak ditimur. Ibukota provinsi ini adalah Kota Mataram yang berada di pulau Lombok. Nusa Tenggara Barat yang terdiri dari Pulau Lombok dan Pulau Sumbawa, memiliki luas wilayah $20.153,20 \mathrm{~km} 2$. Terletak antara $115^{\circ} 46^{\prime}-119^{\circ} 5^{\prime}$ Bujur Timur dan $8^{\circ} 10^{\prime}-9^{\circ} 5^{\prime}$ Lintang Selatan. Selong merupakan kota yang mempunyai ketinggian paling tinggi, yaitu $166 \mathrm{~m}$ dari permukaan laut 
sementara Taliwang terendah dengan $11 \mathrm{~m}$ dari permukaan laut. Dari tujuh gunung yang ada di Pulau Lombok, Gunung Rinjani merupakan tertinggi dengan ketinggian $3.775 \mathrm{~m}$, sedangkan Gunung Tambora merupakan gunung tertinggi di Sumbawa dengan ketinggian 2.851 m.Batas Wilayah: Sebelah Utara dengan Laut Jawa dan Laut Flores, sebelah Selatan dengan Samudra Indonesia, sebelah Barat dengan Selat Lombok (Propinsi Bali), sebelah Timur dengan Selat Sape (Propinsi Nusa Tenggara Timur). Banyak tempat wisata yang disukai dan dikunjungi, 5 diantaranya yang paling popular adalah Trio Gili (Pulau Gili Trawangan, Gili Meno \& Gili Air), Pantai Senggigi, Taman Nasional Gunung Rinjani, Pantai Kuta Lombok, Tanjung Aan (http://www.ntbprov.go.id/tentang_geogra fis.php Diakses 9 April 2014).

Sebagian besar wilayah Nusa Tenggara Barat adalah tanah yang subur yang menjadi sumber utama mata pencaharian penduduk Pulau Lombok yang 90\% adalah Petani. Komoditas tanaman yang menjadi andalan utama para Petani di daerah ini adalah tembakau (mangrove), jagung, padi, kopi, dan kapas. Meskipun Nusa Tenggara Barat memiliki kekayaan alam yang melimpah dan juga menghasilkan padi yang melebihi kebutuhan daerahnya hingga 500.000 ton setara beras, ternyata pada tahun 2008 beberapa kecamatan yang tergolong rawan pangan, yaitu 19 kecamatan di Lombok Timur, 11 kecamatan di Lombok Tengah, 10 kecamatan di Lombok Barat, 9 kecamatan di Dompu, 2 kecamatan di Lombok Utara (Food Security and Vulnerability Atlas of Nusa Tenggara Barat, 2010).

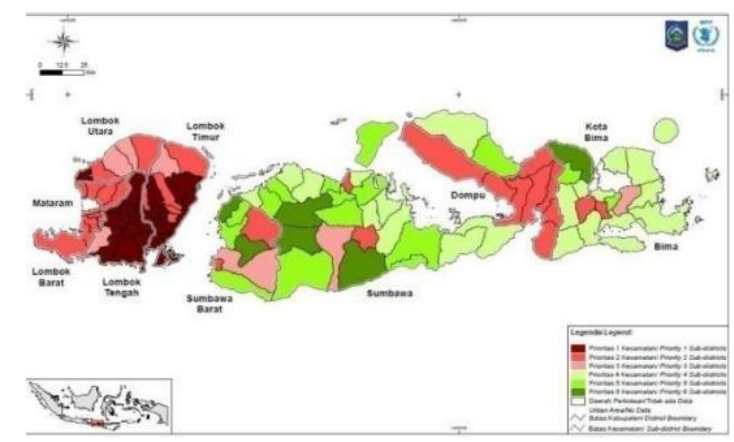

Sumber: (Food Security and Vulnerability Atlas of Nusa Tenggara Barat, 2010).

Gambar 3.4

Peta Kerentanan terhadap Kerawanan Pangan

Provinsi Nusa Tenggara Barat

Dari gambar 3.4, di antara 105 kecamatan tersebut, ditetapkan 64 kecamatan dengan prioritas yang lebih tinggi yang terdiri dari 26 kecamatan Prioritas 1, 31 kecamatan Prioritas 2, dan 7 kecamatan Prioritas 3, dengan jumlah penduduk 3,1 juta orang. 41 kecamatan lainnya dikelompokkan menjadi Prioritas 4-6. Perhatian yang lebih besar perlu diberikan kepada kecamatan yang termasuk dalam Prioritas 1-3.

1. Terdapat 26 kecamatan Prioritas 1, 14 kecamatan di Lombok Timur dan 11 kecamatan di Lombok
Tengah, dengan jumlah penduduk sekitar 1,6 juta orang.

2. Dari 31 kecamatan di Prioritas 2, 10 kecamatan di Lombok Barat, 5 kecamatan di Lombok Timur, dan 9 kecamatan di Dompu, dengan jumlah penduduk sekitar 1,3 juta orang.

3. Dari 7 kecamatan Prioritas 3, 2 kecamatan di Lombok Utara, dengan jumlah penduduk sekitar 202 ribu orang.

Pemetaan ini menggambarkan tingkat kemungkinan terjadinya kerawanan pangan suatu kecamatan secara relatif dibandingkan dengan kecamatan lainnya. Dengan perkataan lain, kecamatan-kecamatan yang berwarna merah memiliki tingkat resiko kerawanan pangan yang lebih besar dibandingkan kecamatan-kecamatan yang berwarna hijau sehingga memerlukan perhatian segera. Meskipun demikian,

Prioritas 1 (warna merah tua) tidak berarti semua penduduknya berada dalam kondisi rawan pangan. Sebaliknya juga pada kecamatan di Prioritas 6 (warna hijau tua) tidak berarti bahwa semua penduduknya tahan pangan.

Nusa Tenggara Barat (NTB) adalah wilayah yang terus aktif menemukan alternatif solusi dalam mengurangi potensi rawan pangan di daerahnya. Terjadinya kasus rawan pangan, menunjukkan bahwa masalah kerawanan pangan bukan masalah yang sederhana dan dapat diatasi sesaat saja, melainkan merupakan masalah yang cukup kompleks karena tidak hanya memperhatikan situasi ketersediaan pangan atau produksi disisi makro saja melainkan juga harus memperhatikan program-program yang terkait dengan fasilitasi peningkatan akses terhadap pangan dan asupan gizi baik ditingkat rumah tangga maupun bagi anggota rumah tangga itu sendiri. Mayoritas keluarga pedesaan di Nusa Tenggara Barat saat ini masih mengandalkan pertanian skala kecil dengan sistem irigasi menggunakan air hujan. Risiko perubahan iklim dan cuaca ekstrim diperkirakan memiliki efek negatif terhadap kehidupan masyarakat di Nusa Tenggara Barat, membuat mereka semakin berisiko mengalami kerawanan pangan yang kronis (http://www.tempo.co/re ad/news/2010/01/31/058222435/Ada-100-Daerah-di-Ka bupaten-se-Indonesia-Rawan-Pangan Diakses 9 April 2014).

Perubahan iklim di Nusa Tenggara Barat merupakan tantangan paling serius yang dihadapi, seiring dengan semakin tingginya dampak dari perubahaniklim seperti peningkatan frekuensi dan intensitas banjir dan kekeringan sertapeningkatan periodisitas El Nino dan La Nina. Perubahan iklim yang dapat berdampak secara signifikan terhadap ketahanan pangan, baik dari aspek ketersediaan, distribusi dan konsumsi serta kualitas pangan dan gizi.

Pemerintah Provinsi Nusa Tenggara Barat terus berupaya mencari solusi agar Nusa Tenggara Barat mengurangi potensi rawan pangan kearah yang kronis, karena Nusa Tenggara Barat dikategorikan sebagai daerah rawan pangan sementara (transitory food insecurity). Dengan kata lain maka kerawanan pangan 
sementara dapat mempengaruhi orang-orang yang berada pada kondisi rawan pangan kronis dan juga orang-orang yang terjamin pangannya pada keadaan normal. Artinya jika kerawanan pangan sementara tidak diatasi maka akan berakibat kerawanan pangan yang kronis. Apabila kerawanan pangan dianalisa dari segi lingkungan hidup, faktor lingkungan dan kemampuan masyarakat untuk mengatasi kerawanan pangan sangat menentukan apakah wilayah dapat mempertahankan ketahanan pangannya. Tinjauan dari sudut pandang lingkungan hidup meliputi perhatian terhadap pengelolaan tanah, pengelolaan air, peningkatan teknologi pra-panen, pelestarian lingkungan hidup dan pengelolaan hutan. Deforestasi hutan melalui eksploitasi sumber daya alam, fluktuasi curah hujan, persentase daerah puso dan persentase daerah yang terkena banjir dan tanah longsor, merupakan beberapa indikator yang di gunakan dalam untuk menjelaskan kerawanan pangan sementara atau transient di provinsi Nusa Tenggara Barat (Food Security and Vulnerability Atlasof Nusa Tenggara Barat, 2010).

\subsection{Metode Penelitian}

\subsubsection{Desain Penelitian}

Untuk melakukan sebuah penelitian, diperlukan sebuah desain atau rancangan yang berisi rumusan tentang objek yang akan diteliti. Metode penelitian yang digunakan penulis dalam penelitian ini adalah menggunakan metode penelitian kualitatif. Merujuk pada permasalahan yang diangkat serta variabel yang tersedia, maka peneliti hanya melakukan analisa data berdasarkan data-data serta informasi yang dikeluarkan oleh World Food Programme (WFP) dan Badan Ketahanan Pangan Nusa Tenggara Barat yang diimplementasikan dengan teori-teori dalam kajian Hubungan Internasional.

\subsubsection{Informan Penelitian}

Dalam melakukan penelitian, adapun pihak yang peneliti jadikan sebagai informan adalah sebagai berikut

1. Staff perwakilan World Food Programme untuk Indonesia. Peneliti berniat untuk mewawancara seputar kinerja World Food Programme secara umum, dan pelaksanaan program Food For Assets di Nusa Tenggara Barat.

2. Staff perwakilan Badan Ketahanan Nusa Tenggara Barat. Peneliti berniat untuk mewawancara seputar kerawanan pangan di Nusa Tenggara Barat.

\subsubsection{Teknik Pengumpulan Data}

Penelitian ini menggunakan metode kualitatif melalui pendekatan sistem, yang didukung oleh teknik pengumpulan data: Studi Kepustakaan, Penelusuran Data Online, Dokumentasi, dan Wawancara. Hal ini dikarenakan penelitian ini difokuskan pada peran suatu organisasi internasional dalam mengatasi permasalahan kerawanan pangan di Nusa Tenggara Barat, dengan mengolah data-data yang diperoleh dari sumber yang relevan secara mendalam.

Studi Kepustakaan, Dalam penelitian ini peneliti menggunakan teknik kepustakaan dengan menelaah teori, opini, membaca buku atau jurnal yang relevan dengan masalah yang diteliti, juga data-data pendukung dari media internet serta media cetak seperti surat kabar, majalah dan sebagainya. Diharapkan dengan teknik studi kepustakaan peneliti dapat mengumpulkan data sekunder.

Penelusuran data online, penelusuran data melalui media online seperti internet atau media jaringan lainnya yang menyediakan fasilitas online, sehingga memungkinkan peneliti dapat memanfaatkan data informasi berupa data maupun informasi teori, secepat dan semudah mungkin dan dapat dipertanggungjawabkan secara akademis. Dalam penelitian ini, peneliti menggunakan layanan internet dengan cara mengakses alamat situs yang terkait dengan kebutuhan penelitian.

Metode Dokumentasi, yakni mencari data mengenai hal-hal atau variabel berupa catatan, transkrip, buku, surat kabar, majalah, brochure dan sebagainya. Dokumen bisa berbentuk tulisan atau gambar.

Wawancara, merupakan salah satu metode pengumpulan berita, data atau fakta untuk memperoleh keterangan. Pelaksanaannya bisa secara langsung, bertatap muka (face to face) dengan orang yang akan diwawancarai atau bisa secara tidak langsung dengan memanfaatkan akses teknologi melalui telepon, internet dan sebagainya. Diharapkan dengan teknik wawancara peneliti dapat mengumpulkan data primer.

\subsubsection{Teknik Penentuan Informan}

Teknik Penentuan informan yang dilakukan peneliti adalah dengan menggunakan teknik Purposive, yaitu teknik penentuan informan dengan pertimbangan tertentu. Metode yang digunakan adalah metode wawancara sesuai dengan masalah yang akan diteliti. Peneliti bertemu dengan narasumber yang menjadi salah satu staff dalam bidang dokumentasi yang secara komprehensif mendeskripsikan seputar programprogram yang dilakukan oleh World Food Programme (WFP) di wilayah Indonesia, terutama di Nusa Tenggara Barat, juga untuk mendapatkan data-data mengenai Annual Report dari program Food For Assets (FFA) World Food Programme (WFP).

\subsubsection{Teknik Analisa Data}

Dalam penelitian kualitatif ini, peneliti menganalisis data dengan menggunakan teknik reduksi data. Artinya, data-data yang diperoleh, baik melalui 
studi pustaka, penelusuran online dan wawancara, digunakan sesuai dengan keperluan penelitan berdasarkan dengan tujuan penelitian. Hal ini bertujuan supaya data yang digunakan berkorelasi dengan perumusan masalah yang telah dibuat. Penyajian Data, peneliti menyajikan data-data yang diperoleh dari hasil meneliti dan wawancara atau dari sumber-sumber internet sesuai dengan kebutuhan. Penarikan Kesimpulan, peneliti menarik kesimpulan dari beberapa data yang disajikan baik data primer atau sekunder yang didapatkan dari informan yakni Perwakilan World Food Programme untuk Indonesia.

\subsubsection{Lokasi dan Waktu Penelitian}

\subsubsection{Lokasi Penelitian}

Dalam penelitian ini penulis memperoleh data dan informasi yang bersumber dari berbagai tempat, diantaranya:

1. Kantor World Food Programme untuk Indonesia, Wisma Keiai, Jl. Jendral Sudirman Kav.3 Lantai 9, Jakarta Pusat.

2. Kantor BPS Pusat, Badan Pusat Statistik (BPS), Jl. Dr. Sutomo No.6-8, Jakarta.

3. Perpustakaan Universitas Komputer Indonesia, Jalan Dipatiukur No.112-114, Bandung.

4. Perpustakaan Universitas Padjajaran, Jalan Dipatiukur No.46, Bandung.

5. Perpustakaan LIPI, Jalan Sangkuriang, Komplek LIPI, Gedung 40, Bandung.

\subsubsection{Waktu Penelitian}

Penelitian ini berlangsung sejak bulan Januari hingga Agustus 2014, yang dirinci sebagai berikut:

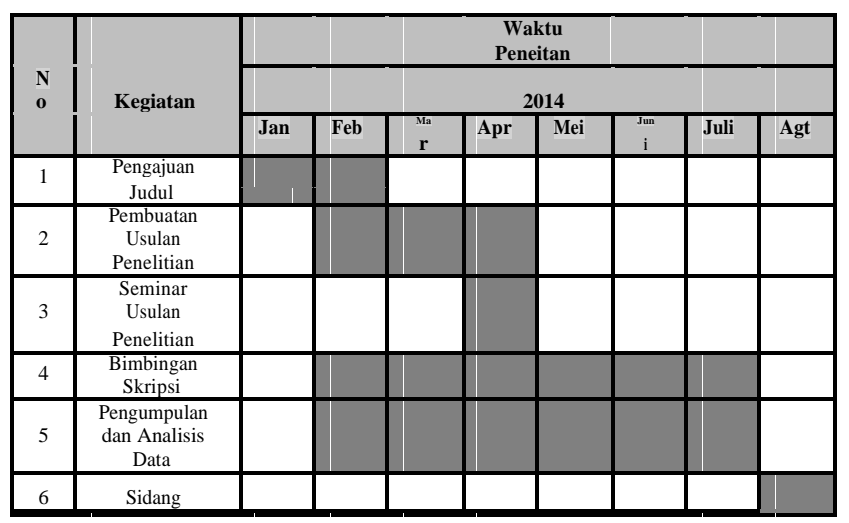

\section{HASIL PENELITIAN DAN PEMBAHASAN}

\subsection{Kondisi Kerawanan Pangan di Nusa Tenggara Barat Sebelum Adanya Program Food For Assets (FFA) World Food Programme (WFP)}

Provinsi Nusa Tenggara Barat diidentifikasi sebagai salah satu yang paling rawan di Indonesia dalam hal kesiapan dan kapasitas untuk beradaptasi dengan dampak perubahan iklim. Ancaman iklim terhadap wilayah meliputi bermacam-macam keadaan yang berhubungan dengan cuaca karena perubahan pola musiman, penurunan yang signifikan dalam musim hujan, dikombinasikan dengan kenaikan suhu. Dampak dari perubahan iklim mungkin secara signifikan meningkatkan ancaman terhadap wilayah yang berpotensi mngalami kerawanan pangan, khususnya masyarakat lokal yang masih menggantungkan atau bergantung pada sistem pertanian tradisional (Wawancara, Badan Ketahanan Pangan Nusa Tenggara Barat).

Menurut data dari Badan Pusat Statistik, musim di Provinsi Nusa Tenggara Barat termasuk jenis tropis dengan musim hujan dari bulan Oktober-Maret dan musim kemarau dari April-September. Provinsi Nusa Tenggara Barat sangat sensitif terhadap perubahan iklim.Pada tahun 2007 terjadi produksi padi dan jagung menurun. Kerusakan padi yang paling parah ditemukan di Bima $(9,85 \%)$, Lombok Tengah $(7,0 \%)$ dan diikuti oleh Dompu $(5,39 \%)$ dan Sumbawa Barat $(2,41 \%)$. Level tertinggi dari kerusakan tanaman jagung di Sumbawa Barat $(40,65 \%)$ diikuti oleh Dompu (10,48\%) (Badan Pusat Statistik, Nusa Tenggara Barat Dalam Angka 2010).

Sebagian besar kerusakan disebabkan oleh bahaya iklim. Jumlah penduduk miskin yang rentan terhadap masalah kerawanan pangan di Provinsi Nusa Tenggara Barat masih cukup tinggi, hal ini sangat berpotensi menyebabkan masyarakat yang masuk kategori miskin akan memiliki masalah dalam mengakses pangan.

Penyebab utama kerawanan pangan yang mengakibatkan kemiskinan adalah keterbatasan keterampilan yang dikuasai, hal ini menyebabkan kesulitan untuk memasuki dan bersaing di lapangan kerja, serta keterbatasan aset dan akses terhadap sumberdaya untuk mengembangkan usaha. Kerawanan pangan dikelompokkan menjadi dua yaitu kerawanan pangan transient atau sementara dan kerawanan pangan kronis. Kerawanan pangan kronis adalah ketidakmampuan masyarakat untuk mengakses pangan sebagai akibat terbatasnya kemampuan secara ekonomi, sedangkan kerawanan pangan transient atau sementara adalah kerawanan pangan yang diakibatkan oleh terjadinya bencana alam, konflik sosial, gagal panen karena kekeringan, serangan hama yang menyebabkan masyarakat mengalami kesulitan untuk mengakses pangan. Kemiskinan penduduk secara langsung dapat berpengaruh pada kerawanan pangan yang sementara ke

kerawanan pangan yang kronis (http://bkp.deptan.go.id/Diakses 15 Mei 2014). 
Meskipun ketersediaan pangan di wilayah Provinsi Nusa Tenggara Barat telah melampaui kebutuhan konsumsi yang ditunjukkan oleh adanya surplus beras sebesar 305.986 ton pada tahun 2007 dan 434.109 ton pada tahun 2008, tetapi kenyataan menunjukkan bahwa di Nusa Tenggara Barat masih ditemukan beberapa wilayah yang belum mampu menyediakan produksi pangan sumber karbohidrat untuk memenuhi kebutuhan penduduknya (rawan pangan), baik dari aspek kuantitas maupun dari aspek kualitas. Di sisi lain, usahatani padi di beberapa wilayah seringkali mengalami kegagalan panen sebagai akibat dari rendahnya ketersediaan sumberdaya air dan serangan hebat hama penyakit. Tingkat kesejahteraan rumah tangga dapat digunakan sebagai salah satu indikator aksesabilitas rumah tangga terhadap pangan. Hal ini juga berkorelasi dengan kemampuan dan daya beli rumah tangga itu sendiri (Badan Ketahanan Pangan, Renstra BKP 2009-2013).

Penciptaan lapangan pekerjaan perlu dikembangkan agar masyarakat mampu meningkatkan pendapatannya. Kondisi kerawanan pangan baik di tingkat wilayah maupun di tingkat rumah tangga akan menjadi ancaman serius bagi perkembangan kesejahteraan masyarakat.

Kerawanan pangan dapat terjadi bukan hanya karena kondisi ketidakmampuan wilayah ataupun ketidakmampuan rumah tangga untuk menyediakan pangan sesuai kebutuhannya, tetapi kerawanan pangan juga dapat terjadi karena adanya kondisi-kondisi transient seperti terjadinya bencana alam yang akibatnya berkepanjangan (WFP Indonesia In Review, 2012).

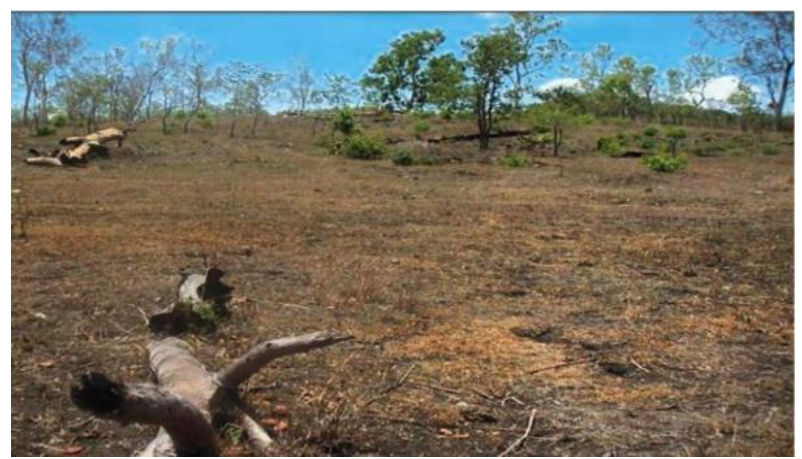

Sumber: (Nusa Tenggara Barat, Factsheet).

Gambar 4.1

Kerusakan Lahan Akibat Perubahan Iklim di Nusa Tenggara Barat

Dalam gambar 4.1, terlihat kerusakan lahan yang diakibatkan oleh perubahan iklim di Nusa Tenggara Barat, hal ini juga bisa disebut degradasi lahan, dimana proses kondisi lingkungan berubah akibat aktivitas manusia terhadap suatu lahan. Perubahan kondisi lingkungan tersebut cenderung merusak. Beberapa bencana alam seperti banjir, longsor, dan kebakaran hutan merupakan hasil secara tidak langsung dari aktivitas manusia sehingga dampaknya bisa disebut sebagai degradasi lahan. Degradasi lahan memiliki dampak terhadap produktivitas pertanian, kualitas lingkungan, dan memiliki efek terhadap ketahanan pangan.

Tabel 4.1

Masalah Kerawanan Pangan Akibat Perubahan Iklim di Nusa Tenggara Barat 2007

\begin{tabular}{|c|c|}
\hline No & Akibat Perubahan Iklim \\
\hline 1 & $\begin{array}{l}\text { Menurunnya daya dukung ekologis yang ditandai } \\
\text { dengan meluasnyadegradasi hutan dan lahan } \\
\text { kritis. Konsekuensinya adalah terjadi penurunan } \\
\text { kualitas dan kuantitas sumberdaya air (mata air } \\
\text { dan sungai) yang diperkirakan akan mengancam } \\
70 \% \text { lahan pertanian dan pasokan air bersih bagi } \\
\text { masyarakat. Dampak ini juga terlihat di daerah } \\
\text { pesisir dan laut dimana terjadi abrasi dan } \\
\text { degradasi hutan bakau yang signifikandan } 44 \% \\
\text { terumbu karang mengalami kerusakan. }\end{array}$ \\
\hline 2 & Meningkatnya intensitas bencana akibat \\
\hline 3 & $\begin{array}{l}\text { perubahan ekstrim pada variabilitas iklim yang } \\
\text { tidak menentu. Hal ini ditandai dengan terjadinya } \\
\text { banjir pada musim penghujan dan kekeringan } \\
\text { pada musim kemarau yang berdampak pada } \\
\text { meluasnya daerah puso pada musim hujan } \\
\text { mencapai } 2,712 \text { ha dan kekeringan pada lahan } \\
\text { padi mencapai } 6,272 \text { ha. Gelombang laut dan air } \\
\text { laut pasang yang terjadi hampir sepanjang tahun } \\
2007 \text { mengakibatkan nelayan kesulitan dalam } \\
\text { mencari nafkah. } \\
\text { Lebih dari } 400 \text { titik mata air di Nusa Tenggara }\end{array}$ \\
\hline 4 & $\begin{array}{l}\text { Barat telah hilang dan telah menyebabkan } \\
\text { terjadinya defisit air akibat menurunnya } \\
\text { ketersediaan air, sementara pemanfaatan air } \\
\text { cenderung semakin tinggi. } \\
\text { Meningkatnya kerentanan sosial akibat usaha tani }\end{array}$ \\
\hline 5 & $\begin{array}{l}\text { dan nelayan yang tidakdapat memenuhi } \\
\text { kebutuhan hidup mereka terutama dalam } \\
\text { pemenuhan pangan, yang pada akhirnya juga } \\
\text { mempengaruhi penghidupan rumah tangga. } \\
\text { Ketidakpedulian dan apatisme para pihak }\end{array}$ \\
\hline \multirow{3}{*}{6} & $\begin{array}{l}\text { terhadap fenomena alam dan kerusakan } \\
\text { lingkungan, baik dari segi kebijakan dan } \\
\text { implementasinya }\end{array}$ \\
\hline & Sistem Informasi penyediaan dan pemanfaatan \\
\hline & $\begin{array}{l}\text { variabilitas iklim belum } \\
\text { optimal. }\end{array}$ \\
\hline
\end{tabular}

Sumber: (Food Security and Vulnerability Atlasof Nusa Tenggara Barat, 2010).

Secara umum, dampak perubahan iklim berkaitan erat dengan kerawanan pangan di Provinsi Nusa Tenggara Barat, berdampak pada turunnya daya dukung lingkungan, terganggunya sumber penghidupan dan kebiasaan-kebiasaan sosial yang terdapat dalam lingkungan masyarakat, seperti kenaikan suhu yang berpotensi meningkatkan kebutuhan air tanaman, menurunkan mutu hasil panen dan meningkatkan peluang berkembangnya hama dan penyakit pada 
tanaman dan ternak unggas dan ruminansia kecil (kambing dan domba). Perubahan pola hujan berpotensi menjadikan penurunan curah hujan pada awal musim panen sehingga dapat terjadi gagal panen. Kekeringan dan curah hujan yang sangat ekstrim pada fase pembungaan atau penyerbukan dapat menyebabkan terjadinya gagal tanam. Potensi penurunan ketersediaan air yang diakibatkan oleh kekeringan yang umumnya terjadi dari sedang hingga tinggi dengan disaat yang bersamaan potensi banjir dari kecil hingga sedang. Di samping itu, laju deforestrasi yang terus meningkat menyebabkan sumber mata air dan sumber irigasi (wilayah DAS) jauh berkurang. Peningkatan suhu udara dan suhu permukaan air laut mengancam terumbu karang di perairan dalam dan habitat ekosistem pesisir

yang berdampak pada menurunnya sumber penghidupan masyarakat nelayan. Tumbuh suburnya organisme yang dapat mengganggu kesehatan manusia seperti malaria dan kolera.

Keadaan ini diperparah dengan pola hidup masyarakat yang belum memperhatikan secara saksama tentang prilaku hidup bersih dan sehat. Banjir, kekeringan dan longsor dapat mengganggu pola dan infrastruktur distribusi pangan sehingga distribusi dan konsumsi pangan tidak efektif dan efisien sampai pada tingkat rumah tangga (Food Security and Vulnerability Atlasof Nusa Tenggara Barat, 2010).

Meningkatnya dampak perubahan iklim yang meliputi perubahan pola hujan yangsemakin tidak menentu, peningkatan suhu udara, meningkatnya kejadian bencana terkait iklim ekstrim, kekeringan, dan banjir, akan semakin memperburuk situasi masyarakat di wilayah-wilayah yang rentan terhadap kerawanan pangan. Hal ini merupakan tantangan serius bagi Nusa Tenggara Barat. Upaya bersama sangat diperlukan untuk melindungi dan memperkuat penduduk yang rawan dalam mengatasi dampak dan beradaptasi terhadap perubahan iklim (Wawancara, Senior Programme Assistant-World Food Programme).

Menurut World Food Programme, ada beberapa hal untuk mengetahui sebab-sebab utama terjadinya kerawanan pangan sementara atau transient di Nusa Tenggara Barat yang timbul akibat perubahan iklim, diantaranya adalah rawannya bencana alam, fluktuasi curah hujan, daerah puso, dan deforestasi hutan.

\subsection{Upaya-upaya yang Dilakukan oleh World Food Programme (WFP) Melalui Program Food For Assets (FFA) dalam Upaya Mengurangi Potensi Rawan Pangan di Nusa Tenggara Barat}

Masyarakat yang mengalami rawan pangan di Nusa Tenggara Barat adalah masyarakat petani yang berusaha mempertahankan hidup dengan mengandalkan sektor pertanian. Dengan segala kemampuan dan keterampilan yang terbatas, namun berusaha untuk meningkatkan kesejahteraan hidup. Oleh karena itu, untuk mengatasi kondisi kerawanan pangan, diperlukan kebijakan yang berpihak kepada pemberdayaan masyarakat maupun membuka peluang kerja bagi masyarakat, sehingga masyarakat memiliki pendapatan dan daya beli untuk mengakses pangan.

Kemampuan yang terbatas membuat mereka terbelakang, dan terlilit dalam kemiskinan. Kemiskinan adalah suatu kondisi yang menyebabkan masyarakat tidak mampu memenuhi kebutuhan pokoknya dan tidak mengaktualisasikan dirinya karena berbagai keterbatasan yang dialaminya (Suryono, 2010:261).

Keadaan tersebut disebabkan karena kerawanan pangan dan persoalan-persoalan lainnya. Untuk mengurangi potensi rawan pangan di wilayah yang mayoritas masyarakatnya bergantung pada pertanian, maka perlu mengoptimalkan bidang-bidang pertanian sebagai jalan utama untuk mengelola potensi sumber daya yang ada melalui kebijakan yang diikuti dengan pola pendampingan yang tepat.

Pemberdayaan masyarakat menjadi hal yang penting dan utama untuk meningkatkan kesejahteraan masyarakat. Pemberdayaan adalah suatu upaya membuat masyarakat dapat mengatur dirinya secara mandiri agar secara bebas mengambil tindakan-tindakan, membuat keputusan-keputusan terhadap apa yang akan ia laksanakan. Pemberdayaan adalah menciptakan kemandirian, baik dari individu, kelompok maupun masyarakat (Wasistiono, 2003:18).

Upaya yang telah dilakukan World Food Programme adalah mengembangkan cara-cara tambahan untuk mengurangi potensi rawan pangan dan berupaya meningkatkan ketahanan pangan sambil beradaptasi terhadap perubahan iklim. Berbagai intervensi World Food Programme di tingkat lapangan sudah mendukung masyarakat untuk mengatasi periode kerawanan pangan dan membantu membangun ketahanan pangan di tingkat masyarakat di Nusa Tenggara Barat. Melalui program Food For Assets (FFA), World Food Programme bekerja sama dengan pemerintah Nusa Tenggara Barat membantu masyarakat dan rumah tangga yang paling rentan mengalami kerawanan pangan sementara atau transient yang berpotensi mengalami kerawanan pangan kronis, dengan kesempatan bekerja untuk menghasilkan aset infrastruktur pertanian dan pedesaan skala kecil yang bermanfaat bagi masyarakat. Aset dirancang untuk memperkuat ketahanan untuk masyarakat bisa bertahan dalam keadaan perubahan iklim, dan untuk mempertahankan mata pencaharian dan ketahanan pangan masyarakat (WFP Indonesia In Review, 2012).

World Food Programme bersama pemerintah Nusa Tenggara Barat telah mengembangkan Peta Ketahanan dan Kerentanan Pangan atau FSVA Nusa Tenggara Barat (Food Security and Vulnerability Atlas of West Nusa Tenggara) untuk tingkat provinsi, kabupaten dan kecamatan di Nusa Tenggara Barat yang memainkan peranan penting dalam mengidentifikasi daerah-daerah rawan pangan dan untuk menargetkan masyarakat yang paling rawan yang bisa mengalami rawan pangan yang kronis diakibatkan oleh risiko perubahan iklim. Sejak tahun 2006, World Food Programme juga telah bekerja sama dengan Badan Penerbangan dan Antariksa Nasional (LAPAN) dan membuat Indonesia Buletin 
Peringatan Dini Bencana Alam. Buletin ini memberikan informasi tentang pola cuaca terbaru dan membuat perkiraan tentang kemungkinan kekeringan, banjir, dan bencana alam lainnya. World Food Programme memperluas kerjasama dengan Badan Ketahanan Pangan dan Badan Meteorologi Klimatologi dan Geofisika (BMKG) untuk meningkatkan dukungan pada sistem monitoring keamanan pangan untuk peringatan dini dan perencanaan respon yang tepat waktu dimana kerawanan pangan bersimpangan dengan risiko iklim (Nusa Tenggara Barat, Factsheet).

Dalam hal meningkatkan hasil pertanian dengan cara yang berkelanjutan, upaya yang dilakukan oleh World Food Programme melalui program Food For Assets adalah penyuluhan pertanian atau pemberdayaan masyarakat yang mengalami rawan pangan, penyuluhan pertanian memegang peran yang sangat penting dalam menyampaikan informasi tentang cara bertani yang baik kepada petani. Adanya perkembangan yang sistematis untuk pengaturan penanaman dalam rangka meningkatkan kesuburan tanah sehingga dapat meningkatkan produktivitas pangan dan ketersediaan pangan yang berkelanjutan. Managemen pengelolaan air diberikan prioritas pada daerah yang memiliki tingkat erosi lahan dan serta aliran air permukaan lahan yang tinggi. Pengukuran yang sederhana seperti saluran air, teras sering, bendungan dan lain-lain dapat memperbaiki kegiatan usahatani. Pengukuran dilakukan oleh kabupaten yang surplus produksi dengan melakukan kegiatan padat karya pangan (food for assets atau food for work) untuk melakukan perbaikan konservasi tanah dan air. Pangan akan dapat membantu rumah tangga yang rawan pangan dalam mendapatkan pangan untuk kebutuhan mereka serta memberikan keuntungan untuk perbaikan kondisi kesuburan tanah dan ketahanan pangan yang berkelanjutan (Nusa Tenggara Barat, Factsheet).

Dalam program Food For Assets di Nusa Tenggara Barat, World Food Programme juga berupaya meningkatkan kesiapan masyarakat dalam menghadapi bencana, masyarakat dipersiapkan untuk menghadapi berbagai macam bencana. Persiapan menghadapi bencana lebih dilakukan dengan cara membentuk suatu kelompok seperti kelompok pengelolaan air dan pemanenan, pengembangan kemampuan masyarakat dalam menghadapi bencana yang mendadak, promosi program reklamasi lahan dan masyarakat hutan dapat membantu meningkatkan sumberdaya dasar sehingga akan dapat meningkatkan kemampuan masyarakat dalam menghadapi tantangan alam (WFP Indonesia In Review, 2012).

Kemampuan untuk memenuhi pangan yang bersumber dari dalam daerah tanpa melalui impor menggambarkan tingkat kemandirian pangan yang baik, dalam arti kebutuhan bahan pangan dapat dipenuhi dari hasil produksi sendiri. Kemandirian pangan harus dapat diwujudkan baik oleh pemerintah maupun masyarakat. Keterbatasan kemampuan pemerintah dalam mengatasi seluruh permasalahan yang ada termasuk didalamnya adalah permasalahan pangan, menuntut adanya kemampuan mandiri dari masyarakat untuk dapat mengatasi permasalahan pangan di lingkungan sekitarnya, terutama di daerah yang bukan sentra produksi pangan.

\subsubsection{Tahapan Terlaksananya Program Food For Assets}

\subsubsection{Kebijakan atau Strategi}

Pelaksanaan program Food For Assets harus memiliki hubungan dengan Kebijakan atau Strategi, antara lain:

1. Saat ini sebagian besar program bantuan Food For Assets sejalan dengan tujuan Operasi Pertolongan dan Pemulihan (Protracted Relief and Recovery Operation-PRRO) No.10069.2, MoU antara Pemerintah Republik Indonesia dengan World Food Programme.

2. Sejalan dengan tujuan nasional: Strategi Penanggulangan Kemiskinan (Poverty Reduction Strategy Paper-PRSP).

3. Meningkatnya minat donor dalam agenda ketahanan pangan.

4. Perjanjian dengan: Departemen Pembangunan Internasional (Department for International Development-DFID), Organisasi Pangan dan Pertanian (Food and Agricultural Organization-FAO) (Food For Assets Briefing Note).

Dalam melaksanakan atau memberi bantuan, World Food Programme memiliki alasan mengapa program Food For Assets dijalankan di Nusa Tenggara Barat, selain wilayah tersebut dikategorikan wilayah yang mengalami rawan pangan transient atau sementara, diantaranya adalah:

1. MoU dengan Pemerintah Republik Indonesia sejalan dengan arah strategis World Food Programme dari Emergency Operation (EMOP) ke Protracted Relief and Recovery Operation (PRRO) dan menciptakan aset untuk membangun ketahanan pangan di setiap wilayah.

2. Penilaian dan studi yang dilakukan oleh lembaga bervariasi menunjukkan bahwa ada kebutuhan untuk mengatasi rawan pangan, dan masyarakat mendapatkan ilmu-ilmu keterampilan melalui keterlibatan dalam program Food For Assets.

3. Pengembangan arah strategis menekankan bahwa kondisi rawan pangan sementara atau transient bisa ditangani oleh kemandirian masyarakat setempat, dan keterampilan yang sudah diberikan World Food Programme 
melalui desining proyek berkelanjutan seperti Food For Assets.

4. Lingkungan yang kondusif dari darurat akibat perubahan iklim ke pembangunan untuk mengembalikan aset-aset masyarakat.

5. Kesiapan Pemerintah Daerah Provinsi Nusa Tenggara Barat, organisasi berbasis komunitas (Community Based Organizations-CBO) dan penerima bantuan (masyarakat) untuk menghubungkan bantuan pangan ke pembangunan daerah.

6. Minat donor untuk mendanai Food ForAssets(Food For Assets Briefing Note).

Food For Assets memiliki dua komponen, yaitu bagian ketahanan pangan dengan menjamin ketersediaan pangan, akses terhadap pangan dan pemanfaatan pangan, dan bagian pembangunan dengan restorasi aset,

keterampilan masyarakat (pemberdayaan) dan pembangunan aset sosial.

\subsubsection{Persyaratan Program Food For Assets}

Upaya lainnya yang dilakukukan oleh World Food Programme, ketika dalam mengimplementasikan program Food For Assets di Nusa Tenggara Barat, hal utama adalah diawali dengan adanya persyaratan program dapat berjalan, yaitu:

1. Seluruh kualitas teknis dari perencanaan hingga pengawasan

2. Pemeliharaan pasca program (harus layak dengan sumber daya yang tersedia secara lokal)

3. Gaji atau bayaran untuk warga yang ikut serta dalam kegiatan Food For Assets diatur dalam referensi untuk tingkat upah lokal dan nilai makanan di pasar local

4. Sumber daya komplementer (yang melengkapi) untuk barang-barang non-makanan ke dalam program Food For Assets (Food For Assets Briefing Note).

Food For Assets tepat diterapkan di Nusa Tenggara Barat dikarenakan masyarakat yang dihadapkan dengan kombinasi defisit pangan musiman, penduduk atau masyarakat di Nusa Tenggara Barat yang mengalami rawan pangan sementara yang terkena bencana alam, masyarakat yang menerima bantuan dari World Food Programme di Nusa Tenggara Barat mampu dan bersedia ikut serta dalam kegiatan yang Food For Assets, karena sebagian besar manfaat juga untuk masyarakat sendiri, program Food For Assets adalah kesempatan bagi penduduk Nusa Tenggara Barat, karena World Food Programme membantu masyarakat untuk keluar dari kondisi rawan pangan dan mulai memulihkan kehidupan dan mata pencaharian mereka agar tidak terjadi rawan pangan yang kronis juga bisa menciptakan ketahanan pangan dan kemandirian pangan masyarakat.

\subsubsection{Target ProgramFood For Assets}

Dalam hal menargetkan suatu wilayah dapat melaksanakan program Food For Assets (FFA), World Food Programme meninjau dari berbagai segi seperti keadaan geografis, adanya dukungan dari pemangku kepentingan: Pemerintah Pusat, Pemerintah Daerah, Mitra Kerjasama (LSM nasional dan internasional), organisasi berbasis komunitas (Community Based Organizations-CBO). Lokasi, wilayah prioritas tinggi dan menengah berdasarkan Kebutuhan Tahunan dan Analisis Mata Pencaharian (Annual Needs and Livelihood Analysis-ANLA), Survei ketahanan pangan dan gizi, termasuk Klasifikasi Terpadu Fase Ketahanan Pangan (Integrated Food Security Phase ClassificationIPC), dan berdasarkan Peta Ketahanan dan Kerentanan Pangan (Food Security and Vulnerability AtlasFSVA).Penerima manfaat atau bantuan, yaitu masyarakat atau daerah yang mengalami rawan pangan, dan wilayah yang mengalami bencana alam. Wilayah yang mengalami rawan pangan sementara akibat perubahan iklim, namun berupaya untuk menghindari dari kerawanan pangan kronis, dan berupaya untuk mencapai ketahanan pangan dan kemandirian pangan, dengan aset produktif (untuk memulihkan keadaan dan mengembangkan keadaan.

\subsubsection{Macam-macam Kegiatan dalam Program Food For Assets}

\section{Kelompok Lumbung Pangan}

Upaya yang dilakukan World Food Programme dalam hal pembinaan akan pentingnya kerjasama dalam kelompok untuk mengatasi masalah seperti pembentukan kelompok lumbung pangan, ada beberapa alasan yang mendasari, pertama Bank Dunia pada tahun 2008 memperingatkan bahwa cadangan pangan Indonesia berada dalam titik terendah sehingga bisa menjadi masalah serius jika tidak diatasi sejak awal mengingat cadangan pangan dunia turun hampir setengahnya, situasi iklim di Nusa Tenggara Barat saat ini tidak menentudankurangbersahabattelah

menyebabkan bencana (longsor, banjir, kekeringan), sehingga menuntut manajemen cadangan pangan yang efektif dan efisien agar dapat mengatasi kerawanan pangan, masa panen tidak merata antar waktu dan daerah mengharuskan adanya cadangan pangan, dan banyaknya kejadian darurat memerlukan adanya cadangan pangan untuk penanganan pasca bencana, penanganan rawan pangan, dan bantuan pangan wilayah. Disamping itu, cadangan pangan juga dapat digunakan untuk mengantisipasi kemungkinan terjadinya kekurangan pangan yang bersifat sementara yang disebabkan gangguan atau 
terhentinya pasokan bahan pangan, misalnya karena putusnya prasarana dan sarana transportasi akibat bencana alam.

\section{Food For Training}

World Food Programme mengadakan pelatihan kepada 104 petani yang tergabung dalam kelompok petani lokal untuk meningkatkan kapasitas mereka pada penanganan paska panen, meningkatkan pengetahuan tentang aflatoksin dan upaya pencegahannya, tentang pengolahan makanan, dan cara memulai usaha kecil. Meningkatkan kesadaran akan risiko aflatoksin dan pencegahannya pada jagung sangat penting di NTB, karena jagung adalah bahan pokok pokok dan aflatoksin merupakan risiko kesehatan yang serius bagi masyarakat. Kelompok tani juga dilengkapi dengan mesin penggilingan jagung. Sekolah dapat menyiapkan makanan bagi anak-anak dengan menggunakan bahan-bahan yang diproduksi dan digiling secara lokal. Semua produk pangan olahan yang digunakan WFP dibeli di Indonesia. Jagung dan kacang hijau, bahan baku dibeli dari kelompok tani yang yang menjalankan program Food For Assets.

3. Mother and Child Nutrition \& School Feeding Tujuan utama dari kegiatan MCN adalah untuk mengurangi defisiensi mikronutrien, antara kelompok rentan anak-anak usia 12-59 bulan, ibu hamil dan menyusui dan untuk meningkatkan kesehatan dan gizi melalui penyediaan biskuit yang diproduksi secara lokal dan mie dengan 9 vitamin dan 5 mineral bersama dengan pendidikan kesehatan dan gizi. Bertujuan untuk meningkatkan partisipasi anak 1-5 tahun dalam pemantauan pertumbuhan dan pemanfaatan layanan ibu dan kesehatan anak yang disediakan di Posyandu. Dilaksanakan di empat kabupaten di Nusa Tenggara Barat (Lombok Tengah, Lombok Barat, Lombok Utara dan Lombok Timur). WFP memberi bantuan 591 Posyandu dan mencapai lebih dari 56.000 penerima manfaat. Aset-aset yang telah dibangun, hasilnya juga selain diberikan kepada masyarakat juga adanya kegiatan penyediaan makanan lokal yang bergizi untuk anak-anak sekolah dan untuk ibu hamil dan menyusui (WFP Indonesia In Review, 2012).

\subsection{Kendala yang dihadapi oleh World Food Programme (WFP) Melalui Pro-}

\section{gram Food For Assets (FFA) dalam Upaya Mengurangi Potensi Rawan Pangan di Nusa Tenggara Barat}

Peneliti melihat selain adanya berbagai upaya yang dilakukan oleh World Food Programme ada pula kendala yang dihadapi, karena pelaksanaan program dari sebuah kerangka kerjasama seringkali ditemukan berbagai kendala yang menjadi hambatan sekaligus tantangan dalam mewujudkan program yang disepakati bersama. Seperti halnya dengan World Food Programme, pelaksanaan program Food For Assets sebagai bentuk upaya mengurangi potensi rawan pangan di Provinsi Nusa Tenggara Barat menghadapi berbagai kendala yang bersifat teknis dan non-teknis, yang berasal dari pihak pelaksana di lapangan yaitu penggagas atau fasilitator dalam kerangka kerjasama WFP.

1. Para Staff World Food Programme yang bertugas didalam program Food For Assets di Nusa Tenggara Barat sering kali kesulitan dalam persoalan akses jalan ke wilayah yang mengalami rawan pangan.

2. Pelaksanaan Food For Assets atau padat karya pangan harus menghindari kegiatan padat karya yang mengganggu ekosistem alam dan sosial, yang menimbulkan bahaya bagi lingkungan dan masyarakat, mengganggu tempat beribadat, juga wilayah yang sulit untuk dipantau.

3. Rawannya terjadi konflik diantara masyarakat setempat yang mendapatkan bantuan, hal ini dikarenakan oleh persoalan lahan pertanian.

4. Sulitnya mendapatkan penterjemah bahasa untuk kebutuhan masyarakat di pedesaan.

5. Kualitas atau keberlanjutan program Food For Assets, adanya kekhawatiran terutama mengingat lingkungan yang rawan, kondisi yang kompleks, risiko yang bisa saja merugikan masyarakat (Wawancara, Senior Programme Assistant-World Food Programme).

Pemerintah Provinsi Nusa Tenggara Barat dan kemitraan World Food Programme (WFP) seperti Badan Ketahanan Pangan Provinsi Nusa Tenggara Barat (BKP) dan Badan Perencanaan Pembangunan Daerah Provinsi Nusa Tenggara Barat (BAPPEDA) dalam pelaksanaan program Food For Assets sebagai bentuk upaya mengurangi potensi rawan pangan di Provinsi Nusa Tenggara Barat juga menghadapi berbagai kendala yang bersifat teknis dan non-teknis, seperti kendala Pemerintah yang terfragmentasi (terpecah belah) dan kurangnya kapasitas. Dan kendala dalam hal monitoring dan evaluasi jangka panjang untuk pengkajian dampak terhadap lingkungan, ketahanan pangan dan mata pencaharian masyarakat. Kendala lain adalah keberlanjutan asset, dikhawatirkan hasil dari program Food For Assets tidak berkelanjutan dikarenakan jangka waktu program yang terbatas. Juga dalam hal pendanaan lanjutan dari Pemerintah (Wawancara, Badan Ketahanan Pangan Provinsi Nusa Tenggara Barat). 


\subsection{Hasil Program Food For Assets (FFA) dalam Upaya Mengurangi Potensi Rawan Pangan di Nusa Tenggara Barat}

Program Food ForAssets di NTB melalui proses konsultasi dengan melibatkan partisipasi masyarakat, pemerintah, LSM. Kegiatan FFA yang telah dituntaskan pada tahun 2010 meliputi konservasi kawasan pesisir dengan penanaman bakau, terasering lahan, penghijauan, dan pembangunan bendungan (DAM). Hasilnya adalah 1.056 hektar wilayah pesisir telah terehabilitasi dengan ditanami lebih dari 2,8 juta pohon bakau (mangrove), 578 hektar lahan pertanian telah mendapatkan manfaat dari pembuatan irigasi baru, dan 11 hektar kawasan silvofishery telah dikembangkan. Masyarakat juga mendapatkan pelatihan mengenai perubahan iklim dan aktivitas yang menghasilkan penghasilan tambahan (Nusa Tenggara Barat, Factsheet).

World Food Programme telah mempertahankan kerjasama yang erat dengan mitra pemerintah terutama pada tingkat provinsi dan kabupaten dalam melaksanakan program Food For Assets, antara lain dengan Badan Ketahanan Pangan (BKP) di bawah Kementerian Pertanian dalam menerapkan dan memperkuat sistem pemantauan ketahanan pangan. Badan Pusat Statistik (BPS), Lembaga Penerbangan dan Antariksa Nasional (LAPAN), Badan Meteorologi, Klimatologi dan Geofisika (BMKG), Kementerian Kesehatan dan Badan Nasional Penanggulangan Bencana (BNPB) merupakan mitra-mitra utama dalam menganalisis ketahanan pangan dari beragam segi, dan Badan Perencanaan Pembangunan Daerah (BAPPEDA) Nusa Tenggara Barat (WFP Indonesiain Review, 2012).

World Food Programme juga menyelenggarakan workshop tiga pihak, dengan petani dan penduduk desa rawan pangan yang mendapatkan bantuan, juga dengan perwakilan pemerintah pusat dan pemerintah daerah, tentang pentingnya sinergi upaya adaptasi perubahan iklim, upaya mengurangi potensi rawan pangan, dan upaya mencapai ketahanan pangan, disertai program kunjungan lapangan di Provinsi Nusa Tenggara Barat. Kontribusi pemerintah diwujudkan dalam bentuk kontribusi tunai, in-kind dan bantuan teknis. Nilai moneter dari kontribusi pemerintah untuk FFA pada tahun 2012 adalah sekitar US \$ 150.000 (total tunai dan kontribusi in-kind). WFP mengharapkan adanya peningkatan kontribusi dari mitra pemerintah dan masyarakat dalam beragam kegiatan sejenis lainnya, melalui partisipasi yang kuat dan komitmen tinggi yang diberikan antara lain oleh Ketua Dewan Pertimbangan Presiden Republik Indonesia (Wantimpres), bagaimana penciptaan kesadaran seluruh masyarakat diangkat pada beberapa isu seputar adaptasi perubahan iklim, perangkat dan solusi melalui kemitraan dengan World Food Programme (WFP Indonesiain Review, 2012).

Program Food For Assets (FFA) World Food Programme yang sudah terlaksana di beberapa daerah di Nusa Tenggara Barat, yang terlaksana pada tahun
2008 hingga 2010, kegiatan Food For Assets tersebut adalah:

1. Dilaksanakan bersama kelompok Ceraken, kegiatan Food For Assets yang dilaksanakan adalah Land development and Food For Training (FFT), kegiatan tersebut dilaksanakan di beberapa tempat di Nusa Tenggara Barat, antara lain di kecamatan Pringgabaya, desa Labuan Lombok. Kecamatan Sambelia, desa Labuan Pandan. Kecamatan Aikmel, desa Aikmel Utara. Kecamatan Selong, desa Denggen. Kecamatan Pujut, desa Mertak. Dan di kecamatan Praya Barat Daya, desa Kateng. Kegiatan tersebut dilaksanakan pada bulan Oktober 2009 hingga April 2009.

2. Kegiatan Food For Assets yang dilaksanakan bersama Forum Pemerhati Masalah Perempuan (FPMP), dilaksanakan pada Oktober hingga Desember 2008, di kecamatan Pujut, desa Teruwai. Kegiatan FFA yang dilaksanakan adalah Agriculture Road dan Plantingjuga Desilting Irrigation Channel, kegiatan Agriculture Road dan Planting dilaksanakan di beberapa dusun seperti Grepek dan Tarung Arung. Sedangkan kegiatan Desilting Irrigation Channel dilaksanakan di dusun BBD II, BBD III, BBD IV Kanan, BBD IV Tengah, BBD IV Kiri, Talat-Talat Selewar, Talat-Talat Sangkung, Penyawung Tego, dan Penyawung Jero Bunut.

3. WFP berkerjasama dengan Yayasan Bina Karya di kecamatan Sambelia, di desa Belanting dusun Menanga Reak, dan di Labuan Pandan dusun Senang Galih dilaksanakan kegiatan Land development (60 ha) dan Irrigation well, dilaksanakan pada Oktober hingga Desember 2008.

4. Bersama Yayasan Keluarga Sehat Sejahtera Indonesia (YKSSI), program FFA dilaksanakan di beberapa kecamatan Bayan, Kayangan, Sekotong, Pujut, Praya Barat, dan Praya Barat Daya. Kegiatan yang dilaksanakan adalah Mother and Child Nutrition \& School Feeding yang terlaksana pada Juni hingga Desember 2008.

5. Bersama Yayasan Satya Dharma Mataram (YSDM) pada bulan Oktober hingga November 2008 di kecamatan Jerowaru dilaksanakan di beberapa dusun seperti Jerowaru BAT, Jerowaru Daye, Sejawe, Pandan, Paek, dan Ketangga Timur. Kegiatannya adalah Agriculture road (2333 metres) dan Desilting irrigation.

6. Pada bulan Oktober hingga Desember 2008, WFP bekerjasama dengan Yayasan Swadaya 
Membangun (YSM), menjalankan program Food For Assets di kecamatan Sambelia, yang terdiri dari beberapa dusun seperti di Pemongkong, Jelok Buso, Oleng, dan UPTPengoros. Kegiatan yang dilaksanakan adalah desilting,embung, dan planting(Wawancara,

Tarningsih Handayani-World Food
Programme).

4.5 Analisa Peranan World Food Programme (WFP) Melalui Program Food For Assets (FFA) dalam Upaya Mengurangi Potensi Rawan Pangan di Nusa Tenggara Barat Tahun 2008-2010

World Food Programme (WFP) sebagai Organisasi Internasional yang menangani bantuan pangan telah melakukan peranannya dalam upaya mengurangi potensi rawan pangan di Nusa Tenggara Barat melalui programnya Food For Assets (FFA). Upaya yang dilakukan World Food Programme sesuai dengan tujuan dan fungi utama World Food Programme yaitu membantu membangun aset dan memperbaiki taraf hidup masyarakat miskin yang mengalami kerawanan pangan khususnya melalui program-programnya, salah satunya ialah program Food For Assets.

Negara-negara yang tergabung dalam keanggotaan suatu Organisasi Internasional berhak meminta bantuan berupa saran, rekomendasi atau aksi langsung berkaitan dengan masalah-masalah dimana Pemerintah tidak dapat mengambil resiko dengan hanya bertindak melalui Kebijakan Nasionalnya. Bahkan saat ini Organisasi Internasional dapat mempengaruhi tingkah laku Negara secara tidak langsung, dimana kehadiran Organisasi Internasional mencerminkan kebutuhan suatu masyarakat dunia untuk bekerjasama dalam menangani suatu permasalahan. Peranan Organisasi Internasional terbagi dalam 3 (tiga) kategori, World Food Programme sebagai Organisasi Internasional

(Intergovernmental Organizations-IGO) dapat dikatakan sebagai:

1. Instrumen, World Food Programe digunakan untuk membantu pemerintah Indonesia dalam menyelesaikan permasalahan kerawanan pangan, untuk Indonsia dapat mencapai ketahanan pangan dan mengurangi kemiskinan di tahun 2015 sesuai mandate World Food Summit. Konsep food resilience (ketahanan pangan) diperkenalkan pada saat badan PBB, Food Agricultural Organization (FAO) mengadakan World Food Summit dan mengeluarkan Deklarasi Roma tentang ketahanan pangan (food resilience) pada 1996 di Roma.

Ketahanan pangan dalam Deklarasi Roma merupakan konsep yang dianut Pemerintah di dalam UndangUndang No.7 Tahun 1996 tentang Pangan. UU tersebut ditindaklanjuti dengan Peraturan Pemerintah Nomor 68 Tahun 2002. Tujuannya adalah terpenuhinya kebutuhan pangan bagi rumah tangga (pasal 1 ayat 17). Pemerintah mengemban tugas utama mengatur, mengendalikan, dan mengawasi ketersediaan pangan dalam jumlah yang cukup, baik jumlah maupun mutunya, aman, bergizi, beragam, merata, dan terjangkau oleh daya beli masyarakat (pasal 45).

Masalah kerawanan pangan menjadi isu penting di dunia internasional. Badan Perserikatan Bangsa Bangsa (PBB) mencatat bahwa setiap lima detik, satu orang meninggal dunia akibat kelaparan di Asia. Walaupun sesungguhnya terdapat pangan yang cukup di dunia ini, hanya saja bahan pangan tersebut tidak mencapai daerah-daerah yang kekurangan. Untuk dapat menangani permasalahan tersebut, World Food Programme yang merupakan salah satu badan PBB dimandatkan untuk menangani masalah pangan dengan berbagai macam upaya.

Kondisi ketahanan pangan global tidak berbeda jauh dengan keadaan di Indonesia, yaitu masih saja terdapat kemiskinan di berbagai negara, terutama di Afrika dan beberapa negara di Asia.Untuk memenuhi komitmen World Food Summit yang menegaskan kembali komitmen deklarasi World Food Summit 1996, yaitu untuk mencapai ketahanan pangan bagi setiap orang dan mengikis kelaparan di seluruh negara. Sasarannya adalah mengurangi jumlah penduduk rawan pangan atau miskin dari 800 juta jiwa pada tahun 1996 menjadi tinggal 400 jiwa pada tahun 2015. Sejalan dengan itu, pangan telah menjadi fokus internasional yang memerlukan upaya, baik antar lembaga pemerintah, lembaga internasional, dan juga peran masyarakat sendiri. Untuk itu, dalam merumuskan paragraf naskah WFS:fyl-2002 dan tindak lanjutnya, maka Pemerintah Republik Indonesia memiliki perhatian terhadap peran hubungan dengan kelembagaan internasional (secara bilateral, multilateral, dan antar lembaga di lingkup PBB) yaitu dengan World Food Programme (WFP), dan peran civil society (LSM atau NGO), urbanisasi, petani miskin, kesempatan kerja, dan program adaptasi perubahan iklim upaya mengurangi potensi rawan pangan dan pengembangan ketahanan pangan.

2. Arena, Indonesia sebagai anggota World Food Programme (WFP) menjadikan Organisasi Internasional tersebut sebagi tempat atau wadah untuk membicarakan dan menggalang kerjasama mengenai permasalahan kerawanan pangan, upaya mencapai ketahanan pangan dan mengurangi kemiskinan di tahun 2015 (mandate World Food Summit), dimana diadakannya pertemuan tahunan Badan Eksekutif World Food Programme (WFP). Pada periode 2003-2005, Indonesia kembali menjadi anggota Executive Board WFP.

Pemilihan Executive Board tersebut dilaksanakan pada sidang ke-123 Dewan Food and Agriculture Organization (FAO) pada 28 Oktober - 2 November 2002 di Roma, Italia. Indonesia sempat berhenti sebagai anggota Executive Board sejak tahun 1997 sampai 
2001, karena pada saat itu Indonesia mendapat kehormatan menjadi ketua Dewan FAO.

3. Aktor independen, dalam menjalankan fungsinya maka Negara-negara anggota World Food Programme (WFP) adalah aktor independen yang bekerjasama untuk dapat menyelesaikan permasalahan yang dihadapi dan melakukannya tanpa adanya pengaruh dari pihak diluar World Food Programme (WFP).

Dalam upaya mengurangi potensi rawan pangan di Nusa Tenggara Barat, WFP bekerjasama dengan sektor pemerintah serta NGO setempat dalam memberikan menjamin kebutuhan pangan dan kemandirian masyarakat, dalam hal menghasilkan pangan, pemberdayaan masyarakat dan mengupayakan untuk mengurangi potensi rawan pangan.

\section{KESIMPULAN DAN SARAN}

\subsection{Kesimpulan}

Dari paparan pembahasan dan hasil penelitian yang peneliti lakukan mengenai peranan World Food Programme (WFP) melalui program Food For Assets (FFA) dalam upaya mengurangi potensi rawan pangan di Nusa Tenggara Barat, maka peneliti dapat menarik kesimpulan sebagai berikut:

1. Provinsi Nusa Tenggara Barat diidentifikasi sebagai salah satu yang paling rawan di Indonesia dalam hal kesiapan dan kapasitas untuk beradaptasi dengan dampak perubahan iklim. Dampak dari perubahan iklim secara signifikan meningkatkan ancaman terhadap wilayah semakin berpotensi mengalami rawan pangan sementara kearah rawan pangan yang kronis, khususnya masyarakat lokal yang masih menggantungkan atau bergantung pada sistem pertanian tradisional. Kerawanan pangan dapat terjadi bukan hanya karena kondisi ketidakmampuan wilayah ataupun ketidakmampuan rumah tangga untuk menyediakan pangan sesuai kebutuhannya, tetapi kerawanan pangan juga dapat terjadi karena adanya kondisi-kondisi transient seperti terjadinya bencana alam yang akibatnya, banyaknya daerah puso, deforestasi hutan. Hal ini merupakan tantangan serius bagi World Food Programme dan Pemerintah Provinsi Nusa Tenggara Barat dalam upaya mengurangi potensi rawan pangan di Nusa Tenggara Barat.

2. Upaya yang telah dilakukan World Food Programme adalah mengembangkan cara-cara tambahan untuk mengurangi potensi rawan pangan dan meningkatkan ketahanan pangan sambil beradaptasi terhadap perubahan iklim. Berbagai intervensi World Food Programme di tingkat lapangan sudah mendukung masyarakat untuk mengatasi periode kerawanan pangan dan membantu membangun ketahanan pangan di tingkat masyarakat di Nusa Tenggara Barat. Melalui program Food For Assets (FFA), World Food Programme bekerja sama dengan pemerintah Nusa Tenggara Barat membantu masyarakat dan rumah tangga yang paling rentan mengalami kerawanan pangan sementara atau transient yang berpotensi mengalami kerawanan pangan kronis, dengan kesempatan bekerja untuk menghasilkan aset infrastruktur pertanian dan pedesaan skala kecil yang bermanfaat bagi masyarakat.

3. Selain adanya berbagai upaya yang dilakukan oleh World Food Programme melalui program Food For Assets di Nusa Tenggara Barat, ada pula beberapa kendala yang dihadapi oleh World Food Programme adalah persoalan kesulitan dalam persoalan akses jalan ke wilayah yang mengalami rawan pangan. Ada beberapa hal yang harus dipastikan bahwa pelaksanaan Food For Assets (food for work) atau padat karya pangan harus menghindari kegiatan padat karya yang mengganggu ekosistem alam dan sosial, yang menimbulkan bahaya bagi lingkungan dan masyarakat, mengganggu tempat beribadat, juga wilayah yang sulit untuk dipantau. Rawannya terjadi konflik diantara masyarakat setempat yang mendapatkan bantuan, hal ini dikarenakan oleh persoalan lahan pertanian. Pemerintah yang terfragmentasi (terpecah belah) dan kurangnya kapasitas. Sulitnya mendapatkan penterjemah bahasa untuk kebutuhan masyarakat di pedesaan. Kualitas atau keberlanjutan program Food For Assets, adanya kekhawatiran terutama mengingat lingkungan yang rawan, kondisi yang kompleks, risiko yang bisa saja merugikan masyarakat. Monitoring dan evaluasi jangka panjang, keberlanjutan asset, pendanaan lanjutan, dan masalah logistik di sekolah yang mendapatkan bantuan makanan sekolah dari hasil pangan lokal melalui program Food For Assets, bahwa tidak memiliki gudang penyimpanan, hal ini menyebabkan makanan disimpan di ruang kepala sekolah.

4. Program Food For Assets di NTB melalui proses konsultasi dengan melibatkan partisipasi masyarakat, pemerintah, LSM. Kegiatan FFA yang telah dituntaskan pada tahun 2010 meliputi konservasi kawasan pesisir dengan penanaman bakau, terasering lahan, penghijauan (Rumah Kebun dan Agroforestry), dan pembangunan bendungan (DAM). Hasilnya adalah 1.056 hektar wilayah pesisir telah terehabilitasi dengan ditanami 
lebih dari 2,8 juta pohon bakau (mangrove), 578 hektar lahan pertanian telah mendapatkan manfaat dari pembuatan irigasi baru, dan 11

hektar kawasan silvofishery telah dikembangkan. Masyarakat juga mendapatkan pelatihan mengenai perubahan iklim dan aktivitas yang menghasilkan penghasilan tambahan. lebih dari 73.000 orang di kabupaten di Nusa Tenggara Barat menerima bantuan. Selain itu, lebih dari 650 petani dan nelayan mendapat pelatihan untuk membantu mereka lebih menjaga hampir 1.250 hektar lahan pesisir dan lahan kritis lainnya. Selain berupaya untuk memperkuat ketahanan masyarakat terhadap bencana, dan mengurangi potensi rawan pangan, program Food For Assets juga memberikan insentif bantuan pangan jangka pendek untuk 11.000 rumah tangga miskin, dan mendukung kesempatan mendapatkan tambahan pendapatan.

5. World Food Programme (WFP) sebagai Organisasi Internasional yang menangani bantuan pangan telah melakukan peranannya dalam upaya mengurangi potensi rawan pangan di Nusa Tenggara Barat melalui programnya Food For Assets (FFA). Upaya yang dilakukan World Food Programme sesuai dengan tujuan dan fungi utama World

Food Programme yaitu membantu membangun aset dan memperbaiki taraf hidup

masyarakat miskin yang mengalami kerawanan pangan khususnya melalui programprogramnya, salah satunya ialah program Food For Assets. Dalam tiga kategori Peranan Organisasi Internasional, maka World

FoodProgrammesebagaiOrganisasi

Internasional (Intergovernmental Organizations-IGO) dapat dikatakan sebagai instrumen, arena, dan aktor independen.

\subsection{Saran}

Dalam penelitian ini banyak menemukan kekurangan baik karena keterbatasan kapabilitas penulis, maupun kendala-kendala non teknis. Untuk lebih mengoptimalkan kinerja World Food Programme (WFP) dalam menjalankan tugasnya, juga untuk Pemerintah, peneliti memaparkan beberapa saran, sebagai berikut:

1. Untuk lebih mengoptimalkan kinerja WFP dalam melaksanakan tugasnya melalui program Food For Assets diharapkan program tersebut dijalankan dalam jangka panjang, di semua sektor, dan di semua wilayah yang mengalami rawan pangan.
2. Program Food For Assets diharapkan diberikan kepada semua wilayah yang mengalami rawan pangan, karena keberhasilan program Food For Assets tidak bisa menjadi acuan bahwa kerawanan pangan di Nusa Tenggara Barat berkurang, karena hanya dijalankan di kecamatankecamatan di Lombok.

3. Untuk Pemerintah diharapkan memperbaiki akses jalan dan infrastuktur di Nusa Tenggara Barat yang masih sulit dijangkau, karena hal tersebut bukan hanya mempersulit masyarakat untuk

mengakses pangan, namun juga mempersulit sampainya bantuan pangan seperti yang diberikan oleh World Food Programme. Maka kendala dalam upaya mengurangi potensi rawan pangan bisa diatasi di semua sektor dan wilayah.

\section{DAFTAR PUSTAKA}

\section{A. BUKU}

Darmawan, Thomas. 2002. Pertanian Mandiri. PT. NIAGA SWADAYA

Dharmaputra, Rizal. 2009. Manajemen Perbatasan dan Reformasi Sektor Keamanan. Jakarta: IDSPS Press.

Hanafie, Rita. 2010. Pengantar Ekonomi Pertanian. Yogyakarta: CV Andi Offset.

Haeruman, Herman. 2001. Kemitraan Dalam Pengembangan Ekonomi Lokal: Bunga Rampai. Yayasan Mitra Pembangunan DesaKota.

Hermawan, Yulius P. 2007. Transformasi dalam Hubungan Internasional: aktor, isu dan metodologi. Jogjakarta: Graha Ilmu.

Khaeron, Herman. 2012. Politik Ekonomi Pangan: Menggapai Kemandirian, Mewujudkan Kesejahteraan. Jakarta: Pustaka Cidesindo.

Perwita, A.A Banyu, dan Yanyan Moch. Yani. 2005. Pengantar Ilmu Hubungan Internasional. Bandung: PT Remaja Rosdakarya.

Rudy, Teuku May. 2009. Administrasi dan Organisasi Internasional. Bandung : PT Refika Aditama.

Shaw, D John. 2001. The UN World Food Programme and the Development of Food Aid. Palgrave.

Soekanto, Soerjono. 2001. Sosiologi Suatu Pengantar. Jakarta: Raja Grafindo Persada.

Sugiono, Muhadi. 2006. Global Governance Sebagai Agenda Penelitian Dalam Studi Hubungan Internasional. Jakarta. 
Suryokusumo, Sumaryo. $1987 . \quad$ Organisasi Internasional. Jakarta: Universitas Indonesia Press.

\section{B. JURNAL DAN KARYA ILMIAH}

Anggeriani, Anita. 2013. PERAN WORLD FOOD PROGRAMME (WFP) DALAM MENANGANI KRISIS PANGAN DI SOMALIA TAHUN 20072009. eJournal Ilmu Hubungan Internasional.

Novrida, Amelia. 2009. PERAN UN WORLD FOOD PROGRAMME (WFP) DALAM MENANGANI KRISIS PANGAN DI INDONESIA 1998-2007. Universitas "Veteran" Jakarta.

Prasetiyani, Ikha dan Dodi Widiyanto. STRATEGI MENGHADAPI KETAHANAN PANGAN (Dilihat Dari Kebutuhan Dan Ketersediaan Pangan) PENDUDUK INDONESIA DI MASA MENDATANG (Tahun 2015 - 2040). Jurnal Bumi Indonesia.

Susetyo, Heru. Dalam Lex Jurnalica Vol.6, No.1, Desember 2008. Menuju Paradigma Keamanan Komprehensif Bersperspektif Keamanan Manusia dalam Kebijakan Keamanan Nasional Indonesia.

\section{PUBLIKASI}

Badan Ketahanan Pangan. Sistem Kewaspadaan $\begin{array}{lll}\text { Pangan dan Gizi } & \text { (SKPG). } \\ \text { PENGANTARSKPG.pdf } & \end{array}$

Badan Ketahanan Pangan. Rencana Strategis Badan Ketahanan Pangan Provinsi Nusa Tenggara Barat, 2009 - 2013.

Badan Pusat Statistik. Nusa Tenggara Barat Dalam Angka, 2010.

Badan Pusat Statistik. Sensus Pertanian Nusa Tenggara Barat, 2009.

Pusat Data dan Sistem Informasi Pertanian. Buletin Konsumsi Pangan. Volume 4 No.1, 2013.

World Food Programme brochure. Bersama Membangun Ketahanan Pangan Indonesia, 2013.

World Food Programme brochure. 2013. Bersama Membangun Ketahanan Pangan Indonesia.

World Food Programme. Food Security and Vulnerability Atlas of Indonesia Brochure, 2009.

World Food Programme. Food Security and Vulnerability Atlas of Nusa Tenggara Barat Brochure. 2010.

World Food Programme. Indonesia In Review, 2012.
World Food Programme. Nusa Tenggara Barat Factsheet, 2012.

World Food Programme. Nusa Tenggara Barat Food For Assets Briefing Note, 2008.

World Food Programme. Stuktur Organisasi World Food Programme, 2013. Documents WFP. Wfp245047.

\section{BUKU KEBIJAKAN DAN PERATURAN PERUNDANGAN}

Memorandum Saling Pengertian Antara Pemerintah Republik Indonesia dan Program Pangan Dunia Perserikatan Bangsa-bangsa Bagi Perpanjangan Operasi Pertolongan dan Pemulihan (No. 10069.2). 2008. Bantuan Untuk Pemulihan dan Rehabilitasi Gizi.

Peraturan Pemerintah Republik Indonesia. Nomor 28 Tahun 2004 Tentang Keamanan, Mutu dan Gizi Pangan. PP-No.-28-Th-2004.pdf

\section{E. RUJUKAN ELEKTRONIK}

About Senior Leadership World Food Programme. Melalui http://www.wfp.org/about/seniorleadership [14/3/14].

About World Food Programme. Melalui http://www.wfp.org/aboutwfp/partners/agencie s.asp?section $=1 \&$ subsection $=4[14 / 3 / 14]$.

About World Food Programme Executive Director. Melalui http://www.wfp.org/about/executivedirector [15/3/14].

Antara News. 2012. 64 Kecamatan di NTB Rentan Rawan Pangan. Melalui http://www.antarantb.com/print/20362/64kecamatan-di-ntb-rentan-rawan-pangan [16/3/14].

Badan Ketahanan Pangan Kementrian Pertanian Republik Indonesia. 2013. Pangan Kebutuhan Dasar Manusia. Melalui http://bkp.pertanian.go.id/ [10/3/14].

Badan Ketahanan Pangan Provinsi Riau. 2013. Daftar Isilah. Melalui http://bkp.riau.go.id/index.php?com=halutama \&link=istilah [11/3/14].

Badan Nasional Penanggulangan Bencana. Bencana Alam Yang Terjadi Di Provinsi Nusa Tenggara Barat Dan Kerusakannya Selama Periode 1990 - 2009. Melalui http://dibi.ntbprov.go.id [15/5/14].

Bambang. 2008. Pemerintah Lanjutkan Kerjasama Program Bantuan Pangan WFP. Melalui 
http://www.antaranews.com/berita/97333/pem erintah-lanjutkan-kerjasama-program-bantuanpangan-wfp [10/3/14].

BBC Indonesia. 2005. Banyak Daerah Indonesia Rawan Pangan. Melalui http://www.bbc.co.uk/indonesian/news/story/2 005/08/printable/050819_indokurangpangan.s html [10/3/14].

Boni Andika. 2011. MILLENNIUM DEVELOPMENT GOALS (MDGs) DALAM PENGENTASAN KEMISKINAN. Melalui http://www.academia.edu/1841758/MILLENN IUM_DEVELOPMENT_GOALS_MDGs_DA LAM_PENGENTASAN_KEMISKINAN [10/3/14].

Danar Widiyanto. 2012. WFP-Pemprov NTB Berkolaborasi Perkuat Ketahanan Pangan. Melalui www.krjogja.com/read/147096/page/tentang_k ami [10/3/14].

Desiana Nurwanti. 2013. Organisasi-organisasi Internasional. Melalui http://www.scribd.com/doc/128230157/Foodand-AgricultureOrganization [15/3/14].

Devi Anggraini. 2012. Aktor Hubungan Internasional. Melalui http://devianggrainifisip12.web.unair.ac.id [5/3/14].

Funding World Food Programme. Melalui http://www.wfp.org/about/funding [14/3/14].

Gembala. 2013. Pengertian Hubungan Internasional dan Organisasi Internasional Menurut Para Ahli. Melalui

http://www.academia.edu/5845406/Pengertian _Hubungan_Internasional_dan_Organisasi_int ernasional_menurut_para_ahli [5/3/14].

Josette Sheeran. 2011. WORLD FOOD PROGRAMME (WFP). Melalui http://www.kemlu.go.id/rome/Pages/Informati onSheet.aspx?IDP=19\&l=id [10/3/14].

Keanggotaan Indonesia di World Food Programme. Melalui http://www.deptan.go.id [15/3/14].

Khofiyati. 2010. Bukti Organisasi Internasional sebagai Subjek Hukum Internasional dan Personalitas Hukum Internasional. Melalui http://khofiyati.wordpress.com/2010/12/13/buk ti-organisasi-internasional-sebagai-subjekhukum-internasional-dan-personalitas-hukuminternasional/ [5/3/14].

Rafika Aulia. 2013. UNDP: Indeks Pembangunan Manusia Indonesia Naik. Melalui http://www.tempo.co/read/news/2013/03/18/08
7467718/UNDP-Indeks-PembangunanManusia-Indonesia-Naik [10/3/14].

Republika Online. 1996. Realisasi Cukup Pangan dalam Food Summit. Melalui http://www.library.ohiou.edu/indopubs/1996/1 1/14/0060.html [10/3/14].

Sumbawa News. 2012. Kecamatan Pujut dan Janapria, Lokasi Padat Karya WFP. Melalui http://www.sumbawanews.com/berita/kecamat an-pujut-dan-jana pria-lokasi-padat-karya-wfp [10/3/14].

Supriyantho Khafid. 2010. Ada Seratus Daerah di Kabupaten se-Indonesia Yang Mengalami Rawan Pangan. Melalui http://www.tempo.co/read/news/2010/01/31/05 8222435/Ada-100-Daerah-di-Kabupaten-seIndonesia-Rawan-Pangan [10/3/14].

Strategic Plan World Food Programme. Melalui http://www.wfp.org/about/strategicplan [14/3/14].

Tempo Interaktif. Undang-Undang Republik Indonesia Nomor: 7 TAHUN 1996 Tentang Pangan. Melalui http://tempo.co.id/hg/peraturan/2004/04/13/prn ,2 0040413-03,id.html [25/8/14].

World Food Programme. Melalui http://www.wfp.org/ [14/3/14].

World Food Programme Cash and Voucher. Melalui http://www.wfp.org/cash-and-vouchers [14/3/14].

World Food Programme Food For Assets. Melalui http://www.wfp.org/food-assets [14/3/14].

World Food Programme HIV AIDS. Melalui http://www.wfp.org/hiv-aids [14/3/14].

World Food Programme School Meals. Melalui http://www.wfp.org/school-meals [14/3/14]. 